\title{
FENOMEN SECESIONISTIČKIH ZAHTJEVA U DEMOKRATSKIM DRŽAVAMA: SLUČAJ KATALONIJE U USPOREDBI SA ŠKOTSKOM
}

Sažetak: $\quad U$ radu je analizirana problematika zahtjeva za odcjepljenjem Katalonije od Španjolske. U prvom dijelu dan je povijesni razvoj katalonskih zahtjeva za samostalnošću i neovisnošću. Nakon toga detaljnije se obraduje suvremeno doba te su ti secesionistički zahtjevi uspoređeni sa zahtjevima škotskih secesionista. Slijedi sustavan pregled $i$ analiza pravnih propisa Španjolske $i$ to $u$ prvom redu ustavnog prava te drugih, u tome kontekstu, relevantnih odredbi unutrašnjeg pravnog poretka. Osim što se analizira imaju li katalonski secesionisti pravo na samoodređenje (i odcjepljenje) po španjolskim propisima, analizirana je $i$ problematika daju li im to pravo propisi medunarodnog i/ili prava EU-a.

Upravo su zahtjevi za samoodređenjem do odcjepljenja izvan kolonijalnog konteksta prema središnjim vlastima u modernim, demokratskim multietničkim državama postali najzahtjevniji i najkontroverzniji u međunarodnom pravu te su izazvali velike debate medu znanstvenicima i stručnjacima. Fenomen secesionističkih pokreta u liberalnim i ekonomski jakim državama tako daju novu dimenziju samoodređenju kao kontinuiranom pravu, pozivanjem na demokratsko pravo izbora i glasanja naroda o pravnoj, političkoj, ekonomskoj i svakoj drugoj budućnosti područja koje naseljavaju. Takvi su primjeri iznimni i rijetki, stoga su važni jer nam daju uvid u pitanje mogu li i kako secesionisti legalizirati $i$ legitimizirati svoje zahtjeve za odcjepljenjem u liberalnim demokracijama.

Ključne riječi: odcjepljenje, samoodređenje, Katalonija, Škotska, EU, međunarodno pravo, ustavno pravo

Dr. sc. Mira Lulić, redovita profesorica na Katedri za međunarodno javno i privatno pravo, Pravni fakultet, Sveučilište Josipa Jurja Strossmayera u Osijeku, Stjepana Radića 13, 31000 Osijek, Republika Hrvatska. Adresa e-pošte: miral@pravos.hr. ORCID: https://orcid.org/0000-0003-3478-5099 


\section{UVOD}

Nema sumnje da su zadnjih godina izbjeglička kriza, secesionistički zahtjevi u pojedinim državama EU-a i Brexit pri vrhu popisa političkih i pravnih problema EU-a. Pitanje odcjepljenja dijela teritorija određene države jedno je od najtežih i najsloženijih pitanja u suvremenoj međunarodnoj zajednici i to s pravnog, etičkog, političkog i ekonomskog aspekta. Opravdan je i strah država od secesionističkih zahtjeva kada znamo da je velika većina današnjih država multietnička. ${ }^{1}$ Posebno su osjetljive one države na čijim teritorijima etničke grupe sklone secesionizmu kompaktno naseljavaju određeno područje i imaju visoko razvijenu autonomiju. Nove države danas mogu nastati okončanjem dekolonizacije, secesijom od postojeće države, raspadom kompletne države na dvije i više manjih ili ujedinjenjem država u jednu. Secesionistički pokreti tako su jedni od najdramatičnijih načina nastanka novih država. Prijete gubitku dijela državnog teritorija, mogu izazvati i raspad države, a usto svaki napredak ili uspjeh secesionističkog pokreta osnažuje i mobilizira secesionističke pokrete u drugim državama. Bez obzira na to kakve simpatije postoje prema secesionističkim pokretima, jasno je da oni donose nove razine nemira i destabilizacije u državama, ali u međunarodnoj zajednici. Secesionističke ambicije, zahtjevi i pokreti različitog su intenziteta, uvjerljivosti i organiziranosti i ne ovise o razini demokratičnosti društva i države. Iako su, naravno, najčešći tamo gdje su teška kršenja ljudskih prava. Pravnih normi nema, kao ni institucionalnih rješenja čak ni smjernica i vodiča koja bi se očekivala od međunarodnih i regionalnih organizacija. Sve se nekako rješava u hodu i improvizira od slučaja do slučaja. Upravo su samoodređenje i zahtjevi za odcjepljenjem primjer koliko snažan utjecaj ima politika na međunarodno pravo.

Međunarodno pravo, a još manje pravo EU-a, do danas nije dalo odgovor na pitanje tko su ovlaštenici prava na samoodređenje, pod kojim uvjetima se to pravo stječe i na koji se način može ostvariti? Nemaju svi narodi pravo na samoodređenje, nisu ga imali niti će ga imati u budućnosti, unatoč proklamacijama prava na samoodređenje u nizu međunarodnih dokumenata. U međunarodnom pravu samoodređenje je, ustvari, vrlo „selektivno i ograničeno u mnogim aspektima“. ${ }^{2}$ Pravo na samoodređenje ne priznaje ni EU ni Vijeće Europe. Uključuje li samoodređenje i pravo na odcjepljenje, odnosno, postoji li situacija kada secesija može biti legitimna i legalna, pogotovo izvan kolonijalnog konteksta? U međunarodnom pravu secesija se ne jamči niti jednim međunarodnim dokumentima, ali nigdje se eksplicitno ne zabranjuje. I to daje nadu secesionističkim pokretima.. Međunarodno pravo zauzelo je, kako Crawford kaže, „neutralan stav prema secesiji“, secesionistički zahtjevi evaluiraju se prema domaćem pravu, dok se međunarodno pravo brine „samo za reguliranje posljedica secesije“. ${ }^{3}$ Europska unija do

1 Termin etničke grupe u ovom se radu rabi na način kako su ga Harff i Gurr definirali u „nebiološkom smislu“ i to kao „psihološku zajednicu“, čiji članovi dijele postojani osjećaj zajedničkog interesa i identiteta utemeljeno u nekoj kombinaciji zajedničkog povijesnog iskustva i kulturnih uvjerenja i osobina, načina života i zajedničke domovine. Radi se relativno velikoj te regionalno koncentriranoj grupi ljudi s poviješću političke neovisnosti ili autonomije koji traže ponovnu uspostavu svoje neovisnosti ili proširenje autonomije. Harff, B., Gurr, T.R., Ethnic Conflict in World Politics, Westview Press, Oxford, 2004, str. 3. i 23.

2 Cassese, A., Self-Determination of Peoples: A Legal Reappraisal, Cambridge University Press, 1998, str. 317.

3 Crawfordov je stav da secesija nije legalna, ali ni ilegalna u međunarodnom pravu, nego da je „legalno neutralni akt“ čije su posljedice regulirane međunarodno. Crawfordova knjiga o Stvaranju država u međunarodnom pravu temeljna je i najvažnija znanstvena monografija na ovu temu, kako u tako i izvan kolonijalnog konteksta. Vidi Crawford, J., The Creation of States in International Law, 2nd edition, Oxford, 2007, str. 390. 
danas se nije zatekla u situaciji da se dio teritorija neke države-članice uspješno odcijepio od matične države. Oba ova slučaja, Katalonije i Škotske, snažno su p(r)otresli i destabilizirali EU.

Kao i na drugim kontinentima, pogotovo multietničke europske države nisu lišene takvih zahtjeva (npr. u Belgiji, BiH, Italiji, Makedoniji, Rumunjskoj, Španjolskoj, UK, Ukrajini itd.). I dok se Europa ujedinjuje, paradoksalno, nacionalističke strasti potresaju ne samo države u kojima se javljaju nego i samu Uniju. Odvojeni kulturni identiteti, posebno različit jezik i/ili vjera secesionističkih regija, svježa sjećanja na povijesne nepravde počinjene nad secesionistima, nezadovoljstvo „krivo“ povučenim granicama među državama, visoko razvijena politička svijest i autonomija, jasno definiran teritorij koji ta grupa dominantno naseljava, a posebno dugogodišnja ekonomska kriza u eurozoni, snažno su potaknuli nacionalističke aspiracije, iredentističke težnje i/ili secesionističke želje.

U radu će biti dan kraći povijesni pregled razvoja katalonskih zahtjeva za neovisnost, današnji argumenti secesionističkih i kontraargumenti antisecesionističkih snaga u toj španjolskoj regiji te, posebno, politika središnjih vlasti u Madridu prema secesionistima. Usporedit ćemo katalonske secesioniste sa škotskima, naglasiti sličnosti i razlike dvaju pokreta za neovisnost, ali i velike razlike u politikama španjolskih i britanskih središnjih vlasti prema secesionistima. Analizirat će se detaljno odredbe unutarnjeg prava Španjolske, u prvom redu Ustav Španjolske iz 1931., a posebno detaljno onaj iz 1978. te Statuti o autonomiji Katalonije iz 1932. i 1979. Konačno, bit će dan i pravni pregled ključnih odredbi međunarodnog i prava EU-a prema secesionističkih zahtjeva.

\section{POVIJESNI RAZVOJ KATALONSKOG IDENTITETA I ZAHTJEVA ZA NEOVISNOŠĆU}

Katalonija ima dugu i bogatu povijest i kulturu kao, uostalom, sama Španjolska. Ta povijest ispunjena je različitim razinama političke, pravne i ekonomske samostalnosti Katalonije, borbama i savezništvima s moćnim susjedima, ulascima u unije i izlascima iz njih, ratovima i pregovorima te jačanjem i slabljenjem katalonskog identiteta. Katalonski nacionalisti često se $u$ argumentima za neovisnost pozivaju na ta povijesna događanja, naglašavajući time dugu tradiciju odvojenog etničkog identiteta Katalonaca od ostatka Španjolaca. ${ }^{4}$

Katalonija se kao zaseban i definiran teritorij javlja u 12. st., a dijelom Španjolske postaje u 15. st. brakom kralja Ferdinanda i Izabele od Kastilje. Od tog razdoblja regija se postupno integrira u španjolsku državu. U Srednjem vijeku Katalonija je bila ekonomski jaka, a posebno je bila poznata kao velika pomorska sila na Mediteranu. Svoj snažni ekonomski razvoj započinje valom industrijalizacije u 19. st. Taj period poklapa se i sa snažnom renesansom katalonske kulture. Iako je Katalonija stoljećima postojala kao zaseban entitet, ideologija katalonskog nacionalizma nije se razvila do 19. st., kada su modernizacija i ekonomski napredak u cijelosti

4 Kleiner-Liebau, D., Migration and the Construction of National Identity in Spain, Iberoamericana Editorial Vervuert S.L.U, Madrid, 2009, str. 67. 
transformirali katalonsko društvo. ${ }^{5}$ Katalonska kulturna i politička svijest jačala je sve više, kao i porast katalonskog nacionalizma kao organiziranoga političkog pokreta. ${ }^{6}$

\subsection{OD REPUBLIKE DO FRANCOVE DIKTATURE}

Prva važna godina u katalonskoj povijesti 20. st. jest 1931., kada je Španjolska proglašena Republikom. Proklamiranjem Republike tadašnji španjolski kralj Alfonso XIII. odlazi u egzil. Španjolski Parlament dopušta „organizaciju autonomnih regija unutar španjolske države provincijama sa zajedničkom povijesti, kulturom i ekonomijom", stoga je Katalonija dobila autonomiju. Tako su početkom 30-ih formirana dva regionalna autonomna područja - baskijsko i katalonsko. U skladu s Ustavom Španjolske iz 1931. godine (čl. 11.) organizirane su posebne autonomne regije unutar Španjolske i to na temelju područja sa „zajedničkom povijesti, kulturom i ekonomijom". ${ }^{7}$ Svaki predloženi statut o autonomiji morao je odobriti španjolski Parlament i to nakon održanog plebiscita o autonomiji u konkretnoj autonomnoj regiji. Zanimljivo je da je tada jedino Katalonija iskoristila tu mogućnost, dok su Baskija i Galicija svoje autonomne statute predložile 1936. godine, no Španjolski građanski rat (1936.-1939.) onemogućio je njihovo stupanje na snagu ${ }^{8}$. Donošenjem Statuta o autonomiji Katalonije (1932.), novoformirani katalonski Generalitat dobio je administrativne odgovornosti, iako ne i zakonodavnu moć. ${ }^{9}$

Taj je period početak duboke podjele u španjolskom društvu i državi, sukoba desnice i ljevice, nacionalista i komunista, monarhista i republikanaca. Kao kulminacija tih oprečnih vizija i želja o budućnosti Španjolske, izbija brutalan Španjolski građanski rat (1936.-1939.). „Katalonsko pitanje“ već je tada bilo jedno od gorućih pitanja u Španjolskoj koje je ih, između ostalog, i odvelo u građanski rat. ${ }^{10}$ Pobjedom generala Francisca Franca, kratak republikanski period Španjolske okončan je 1939. godine i time su spriječeni svi daljnji pokušaji regionalizacije španjolskih pokrajina. ${ }^{11}$ Time prestaje samouprava Katalonije, zatvara se katalonski Generalitat, a u Španjolskoj počinje gotovo četiri desetljeća duga (fašistička) diktatura. ${ }^{12} \mathrm{U}$ cijeloj Španjolskoj krše se temeljna ljudska prava i sustavno se ukidaju demokratske institucije. U Španjolskom građanskom ratu i nakon njega, procjenjuje se, oko 100.000 ljudi poslano je u zatvore i radne logore i oko 150.000 u koncentracijske logore. Poginulo je od 54.000 do 59.000

5 McRoberts, K., Catalonia: Nation Building without a State, Oxford University Press, 2001, str. 2. cit. prema ibidem, str. 68.

$6 \quad$ Ibidem, str. 56.

7 Među zakonodavnim i izvršnim ovlastima posebno rezerviranima za središnje španjolske vlasti bila su pitanja, primjerice, stjecanja državljanstva, odnosa države i crkve, nacionalne obrane, vanjskih poslova, carine i tarifa, uključujući trgovačke ugovore, monetarnu politiku i bankarski sustav te komunikacije (čl. 14. Ustava Španjolske iz 1931.). Hannum, H., Autonomy, Sovereignty, and Self-Determination, University of Pennsylvania Press, Philadelphia, 1996, str. 265.-266.

8 O katalonskom Statutu o autonomiji i političkoj situaciji u Španjolskoj 30-ih detaljnije vidi u Lulić, M., Pravo na samoodređenje u suvremenom međunarodnom pravu, doktorska disertacija, Pravni fakultet, Zagreb, 2005. (u daljnjem tekstu: „Lulić, Pravo na samoodređenje u suvremenom međunarodnom pravu“), str. 279.-280. i dalje.

9 Kleiner-Liebau, op. cit. (bilješka 4), str. 69.

10 Ehrlich, C. E., Ethno-Cultural Minorities and Federal Constitutionalism: Is Spain Instructive, Southern Illinois University Law Journal, Vol. 24, No. 2, 2000, str. 301.

11 Vidi detaljnije Galindez, J. De, Spain, Columbia Law Review, Vol. 54, No. 5, 1954, str. 809.-820.

12 Connolly, C. K, Independence in Europe: Secession, Sovereignty, and the European Union, Duke Journal of Comparative \& International Law, Vol. 24, No. 51, 2013, str. 56. 
Katalonaca, 60.000 postalo je radno nesposobno zbog ranjavanja, a od 60.000 do 70.000 ljudi emigriralo je. ${ }^{13}$

Kao posljedica toga da je Katalonija bila jako uporište republikanaca u Španjolskom građanskom ratu, uslijedila je teška odmazda Franca prema Kataloncima, uostalom kao prema svim drugim španjolskim regijama koje su se borile protiv njega. U državi gdje su se tradicionalno rabila tri jezika (kastiljanski španjolski, katalonski i baskijski) te čitav niz različitih dijalekata, Franco je zabranio bilo kakve regionalne kulturne (i jezične) razlike. Diktatorsku vladavinu generala Franca mnogi Katalonci vide kao „najmračniji period katalonske povijesti““. ${ }^{14}$ Ukidaju se političke stranke, ubijaju se ili zatvaraju vođe i pristaše Republike te se potpuno zatiru, između ostalih, katalonski grupni identitet i kultura. Zabranjuje se uporaba katalonskog jezika, davanje djeci katalonskih imena, katalonska su prezimena kastiljizirana, a u školama se uči isključivo kastiljanski španjolski. Zabranjena je uporaba katalonske zastave, uništeni su povijesni spomenici, zatvorene su povijesne institucije i uklonjeni svi natpisi na katalonskom jeziku. ${ }^{15}$ Individualna i grupna ljudska prava sustavno su se i teško kršila sve do Francove smrti 1975. godine i početka demokratizacije države krajem 70-ih. Posljedice i traume za većinu Katalonaca bile su teške i trajne, a ogorčenost zbog povijesnih nepravdi nije jenjavala s vremenom. Pozitivna stvar u tom razdoblju bila je ta da je Katalonija u međuvremenu, od 60-ih godina, prolazila snažan ekonomski razvoj, pogotovo u pogledu industrijalizacije i razvoja turizma. Ta će činjenica Kataloncima poslije dati dodatno samopouzdanje i osjećaj da su ekonomski dostatni za samostalan život, bez ostatka Španjolske.

\subsection{USTAV ŠPANJOLSKE (1978.) I STATUT O AUTONOMIJI KATALONIJE (1979.)}

Nakon Francove smrti španjolsko društvo i država počinju se demokratizirati i Španjolska ulazi u stanje moderne i stabilne europske države. Za razliku od SFRJ-a desetak godina poslije, Španjolska je puno opreznije započela proces demokratizacije, poduzeti su veliki napori da ne dođe do sukoba i nasilja među etničkim grupama jer su traume Španjolskog građanskog rata još uvijek bile svježe u ljudskim sjećanjima. ${ }^{16}$

Jedna od najkritičnijih točki budućeg španjolskog ustava bila je vezana upravo uz „katalonsko pitanje“, ali i generalno priznanje različitih kulturnih grupa u Španjolskoj. ${ }^{17}$ Već 1977. godine organizirani su demokratski izbori za španjolski Parlament i sedmeročlano vijeće, tzv. „očevi Ustava“; trebalo je donijeti nacrt novog Ustava. Među njima su, na što središnje vlasti u Madridu često podsjećaju, bila i dvojica Katalonaca. ${ }^{18}$ Nakon referenduma o tome prihvaćaju

13 Ćurko, H., Profil autonomne zajednice Katalonija. Zemlja na političkom raskrižju (u daljnjem tekstu: „Ćurko: Profil autonomne zajednice Katalonije“), Političke analize, god. 4, br. 15, rujan 2013., str. 45.

14 General Franco bio je „odlučan konačno jednom za svagda riješiti katalonski problem“. McRoberts, op. cit. (bilješka 5), str. 13., cit. prema Connolly, op. cit. (bilješka 12), str. 56.

15 McRoberts, op. cit. (bilješka 5), str. 41. cit. prema Kleiner-Liebau, op. cit. (bilješka 4), str. 72.

16 Ehrlich, op. cit. (bilješka 10), str. 300.

17 Ibidem, str. 301.

18 Baskijci su, primjerice, odbili sudjelovati u tom Povjerenstvu. O sastavu Ustavnog povjerenstva iz 1977. vidi ibidem, str. 304.305. Detaljnije o Baskiji vidi Lulić, M., Muhvić, D., Status Baskije u Španjolskoj: odcjepljenje versus decentralizacija, Pravni vjesnik, god. 21, br. 3-4, 2005., str. 287. i dalje. 
li Španjolci prijedlog novih ustavnih rješenja, na snagu je ubrzo stupio nov Ustav Španjolske 1978. U Ustavu Španjolske (1978.) u čl 2. navodi se, inter alia, da se „Ustav temelji na neraskidivom jedinstvu španjolske nacije, zajedničke i nedjeljive domovine svih Španjolaca, priznaje i garantira pravo na samoupravu nacionalnosti i regija od kojih se sastoji i solidarnost među njima“. ${ }^{19}$ Tu treba uočiti pravno-jezične finese da se Španjolska definira kao „nacija“ (Nación), a Katalonci, Baskijci, Galijci i drugi kao - „nacionalnosti“ (nacionalidades). ${ }^{20}$ Sve te različite „nacionalnosti“ čine jedinstvenu „španjolsku naciju“. Osim što je „španjolska nacija nedjeljiva“, prema Ustavu, podsjetimo, španjolska vojska ima pravo štititi teritorijalni integritet Kraljevstva (čl. 8.). Konačno, u tom kontekstu, važna je i odredba čl. 472. t. 5. Kaznenog zakona Španjolske prema kojoj je secesija (declarar la independencia de una parte del territorio nacional) kazneno djelo izjednačeno s pobunom..$^{21}$

U pogledu teritorijalne organizacije španjolske države prema Ustavu iz 1978., važan je čl. 137. španjolskog Ustava. Tim člankom uvodi se posebna teritorijalna organizacija podijeljena na: „samoupravne općine“ (municipios), provincije (provinicias) i autonomne zajednice (comunidades autónomas). U čl. 143. Ustava Španjolske navode se nacionalnosti i regije koje mogu uspostaviti „autonomne zajednice“. Tako se u spomenutom članku navodi da „provincije sa zajedničkim povijesnim, kulturnim i ekonomskim obilježjima, otočnim područjima i provincije s povijesnim regionalnim statusom“ mogu uspostaviti autonomiju i „autonomne zajednice“. „Jedinstvo“ španjolske nacije i „autonomija“ postaju temelj španjolskoga državnog uređenja. ${ }^{22}$ Već sljedeće godine, na temelju Ustava iz 1978., počinju se donositi pojedinačni regionalni statuti o autonomiji.

Španjolska se u Europi uzima kao „uspješna u održavanju svog identiteta kao jedna država“, no nije riješila pitanje nacionalnosti koje je postalo kritično i koje, sada već desetljećima, dominira ustavnim debatama. ${ }^{23}$ Naime, statuti autonomija uzimaju se kao „uspješan miks regionalizma i federalizma sa supremacijom središnje vlasti““. ${ }^{24}$ No, u praksi je situacija bila prilično složena. Statut o autonomiji Katalonije (Estatuto de Autonomía) donesen je 1979. kao organski zakon. Tim aktom uspostavljeni su katalonski Parlament, predsjednik i Vlada u Kataloniji (Generalitat de (atalunya). Nakon Katalonije slični referendumi o autonomiji i usvajanja statuta o autonomiji uslijedili su u drugim španjolskim regijama. Inače, autonomne zajednice nemaju iste karakteristike, nego imaju različite ovlasti i razine autonomije. Primjerice, u Statutu autonomija Katalonija, Baskija, Andaluzija i Galicija priznate su i kao posebne „povijesne zajednice“ unutar Španjolske i kao takve uživaju puno veće ovlasti u odnosu na sve druge autonomne zajednice u Španjolskoj, ${ }^{25}$ što nije naišlo na odobravanje u španjolskom političkom životu.

\footnotetext{
19 Constitución Española, Diario oficial Boletín Oficial del Estado, de 29 de diciembre de 1978, BOE-A-1978-31229.

20 Ćurko, Profil autonomne zajednice Katalonija, op. cit. (bilješka 13), str. 46.

21 Za to je kazneno djelo za vođe takve pobune predviđena zatvorska kazna od 15 do 25 godina (čl. 473. st. 1.). Del Código Penal, Diario oficial Boletín Oficial del Estado, de 24 de noviembre 1995, última modificación: 28 de abril de 2015, BOE-A-2015-3439. Gotovac, M., Kostadinov, B., Autonomne zajednice u Španjolskoj, Pravnik: časopis za pravna i društvena pitanja, god. 42, br. 86, 2008., str. 24.

23 O Ustavu Španjolske vidi Ehrlich, op. cit. (bilješka 10), str. 298. i dalje.

24 Ibidem.
}

25 De Estatuto de Autonomía de Cataluña, oficial Boletín Oficial del Estado, de 22 de diciembre de 1979, BOE-A-1979-30178; de Estatuto de Autonomía para el País Vasco, oficial Boletín Oficial del Estado de 22 diciembre de 1979, BOE-A-1979-30177; de Estatuto de Autonomía para Galicia, oficial Boletín Oficial del Estado de 28 de abril de 1981, BOE-A-1981-9564. 
Iako su autonomne zajednice analogne saveznim državama u federacijama i iako se Španjolska voli smatrati jednom od najdecentraliziranijih država na svijetu, važno je naglasiti da Španjolska nije federalno uređena, nego visoko decentralizirana unitarna monarhija. Takvim državnim uređenjem Španjolska je, ustvari, postala nekakva „polufederalna višejezična država“. Zato neki španjolski sustav zovu tzv. „devolucijskim federalizmom“. ${ }^{26}$ Službeno, Španjolska je Ustavom iz 1978. postala parlamentarna ustavna monarhija s kraljem kao predsjednikom države. Iako, dakle, Ustav ima puno federalnih elemenata i de facto predviđa federalizaciju Španjolske osnivanjem autonomnih zajednica, namjerno se nigdje ne spominje pojam federacije niti se autonomne zajednice igdje spominju kao „konstitutivne jedinice“. ${ }^{27}$ Vieytez definira španjolsko ustrojstvo kao „odmak od tradicionalne unitarne države“, ali i onih koje su djelomično decentralizirane (npr. UK, Danska ili Finska) ili se razlikuju od klasičnih federalnih modela (kao Njemačka, Austrija ili Švicarska). ${ }^{28}$ Smatra da je Španjolska najbliža Italiji, različitoj po tome da jamči asimetriju regija u samom tekstu Ustava (što Španjolska ne navodi). ${ }^{29}$ Španjolska se i naziva „Država Autonomija“ (Estado de las Autonomías). ${ }^{30}$

Razlozi su, naravno, političke prirode i povezani su sa složenim i vrlo osjetljivim političkim prilikama u španjolskom društvu i državi. „Teritorijalno ustrojstvo“ Španjolske nije se navodilo u Ustavu radi, u prvom redu, izbjegavanja uporabe koncepata „federalna“ ili „unitarna“ jer bi različite političke grupe zbog takvih „detalja“ mogle u cijelosti opstruirati usvajanje teksta Ustava, pa tako i proces demokratizacije društva. ${ }^{31} \mathrm{I}$, drugo, jer se razvoj španjolskog teritorijalnog modela, ustvari, 1978. godine još nije ni dogovorio, čak ni u svojem većem dijelu. ${ }^{32}$ Desne političke stranke i „frankisti“, očekivano, uvijek su se protivili konceptu „nacionalnosti“ jer su u njemu vidjeli „legitimiranje secesionističkih zahtjeva“. ${ }^{33}$ Osim unionistima, privilegiranje određenih autonomnih zajednica i taj sustav asimetričnog „kvazi-federalizma“ nije po volji onim autonomnim zajednicama kojima su dodijeljena manja prava. U Španjolskoj tako kontinuirano traje podjela što se tiče (a)simetrije, gdje se asimetričnosti autonomnih zajednica suprotstavljaju zagovornici primjene direktne simetrije. ${ }^{34}$ Primjerice, kao ustupak centralistima, iako se može činiti kontradiktorno, središnja, najveća, najbrojnija i politički najmoćnija regija Kastilja podijeljena je na niz gotovo izmišljenih, u svakom slučaju, „povijesno nepostojećih regija“. 35

26 Ćurko, H., Politike nacionalnog identiteta slučajevi Španjolske i francuske Baskije (u daljnjem tekstu: „Ćurko, Politike nacionalnog identiteta"), Fakultet političkih znanosti Sveučilišta u Zagrebu, Zagreb, 2016, doktorska disertacija, str. 85. i 87. Lecours, A., Basque Nationalism and the Spanish State, University of Nevada Press. The Basque series, Reno, 2007, str. 86., cit. prema ibidem, str. 87.

Vieytez, E. R., A New Political Status for the Basque Country, Journal on Ethnopolitics and Minority Issues in Europe, Vol. 12, Issue 2, 2013, str. 86 . Ibidem.

30 Lecours, op. cit. (bilješka 27), str. 86, cit. prema Ćurko, Politike nacionalnog identiteta, op. cit. (bilješka 26), str. 87.

31 Vieytez, op. cit. (bilješka 28), str. 85.

32 Ibidem.

33 Ćurko, Politike nacionalnog identiteta, op. cit. (bilješka 26), str. 86.

34 Vieytez,op. cit. (bilješka 28), str. 88.

35 Autonomija je inicijalno bila zamišljena samo za tri „nacionalnosti“: Kataloniju, Baskiju i Galiciju. No, uskoro su i druge regije počele tražiti ista prava: Andaluzija, Kanarsko otočje, Baleari, Valencija i Aragon. Ove prve autonomne zajednice nisu željele izgubiti svoj privilegirani status i nisu ga htjele „dijeliti“ s drugima. No, konkurencija među regijama stalno je prisutna. Vidi Curko: Politike nacionalnog identiteta, op. cit. (bilješka 26), str. 85-87. 
Kada je riječ o ovlasti, prema čl. 149. st. 1. Ustava, središnja vlast ima isključivu nadležnost za trideset dva područja (npr. međunarodni odnosi, obrana, sudstvo, radno zakonodavstvo, civilna legislacija, imigracija, obrana španjolske kulture itd.), dok autonomne zajednice, u skladu s čl. 148. st. 1., dobivaju ovlasti u dvadeset dva područja (npr. samouprava, turizam, sportske luke, ribarenje u rijekama, zaštita spomenika kulture i regionalnog jezika, lokalnog gospodarstva, poljoprivrede i stočarstva, promoviranje kulture, zdravlje i higijene itd.). U Španjolskoj je danas sveukupno sedamnaest takvih autonomnih zajednica, pedeset je provincija i dva su autonomna grada (Ceuta i Melilla). Službeni jezik u Španjolskoj jest kastiljanski (španjolski), a autonomne zajednice na svojem teritoriju mogu odrediti i drugi jezik kao službeni uz kastiljanski. Samo šest autonomnih zajednica (Baskija, Navarra, Katalonija, Valencija, Baleari i Galicija) proglasilo je, na temelju autonomnih statuta, svoje jezike službenima zajedno s kastiljanskim te su stipulirale da je zaštita njihovog regionalnog jezika legitiman zadatak države. ${ }^{36}$ Promoviranje katalonskog jezika postalo je, između ostalog, središnji dio regionalne politike Katalonije. ${ }^{37}$ Katalonske vlasti imaju stav da je Katalonac svatko tko živi i radi u Kataloniji; katalonski jezik jedan je od ključnih elemenata diferencijacije Katalonije od ostatka Španjolske i katalonska jezična politika ključan je element za integriranje stanovništva. ${ }^{38} \mathrm{Na}$ taj način, tvrdi Carla, stanovništvo u Kataloniji ne bi bilo podijeljeno po etničko-jezičnim linijama, nego bi katalonske politike išle na integraciju, ako ne i asimilaciju kastiljanskih govornika i njihove kulture u „katalonski nacionalni projekt“ ${ }^{39}$

Generalno rečeno, španjolski Ustav proizvod je kompromisa, no taj tekst, kako se pokazalo, ne rješava temeljna pitanja i stvorio je, praksa će pokazati, previše kontradikcija koje je gotovo nemoguće korigirati amandmanima. ${ }^{40}$ Tako će kontinuirana dramatična ustavna debata ostati konstantom u španjolskoj politici i društvu, a španjolski će Ustav potaknuti istraživanja i u pravu i u politologiji. ${ }^{41}$

\subsection{ZAHTJEVI ZA NEOVISNOŠĆU KATALONIJE (2005.-2018.)}

Godine 2005. godina promijenjen je tekst Statuta o autonomiji Katalonije iz 1979. godine. Na izbore o reviziji Statuta izašlo je samo 49 \% birača, od kojih je njih 74 \% bilo „za“ promjene teksta Statuta. Novi Statut stupio je na snagu 2006. godine. ${ }^{42}$ No, nije sve proteklo bez prav-

36 Baskija, Katalonija, Galicija i Baleari deklariraju da su baskijski, katalonski i galicijski „njihovi vlastiti jezici“ (lengua propia). Xabier, A., Linguistic Minorities in Spain, u: Richter, D. et al., (eds.) Language Rights Revisited - The Challenge of Global Migration and Communication, Wolf Legal Publishers, Berliner Wissenschafts-Verlag, 2012, str. 273.

Godine 1993. Katalonija je uvela jednojezično obrazovanje na katalonskom jeziku za djecu između tri i osam godina, što je 1994. godine potvrdio i španjolski Ustavni sud. U doba Francove smrti, 60 \% Katalonaca pričalo je katalonski, a taj je broj 2001. porastao na 76 \%. Vidi: Borgen, C. J., From Kosovo to Catalonia: Separatism and Integration in Europe (u daljnjem tekstu: „Borgen, From Kosovo to Catalonia“), Goettingen Journal of International Law, Vol. 2, No. 3, 2010, str. 1017-18.

Vidi Carla, A., Institutions, Ethno-nationalism, and Sense of Belonging: Comparing Separatist Tendencies in Catalonia and South Tyrol, 11 European Yearbook of Minority Issues, Issue 1, 2012, str. 110, bilješka 86. i autore koje tamo navodi.

40 Ehrlich, op. cit. (bilješka 10), str. 314.

41 Ibidem, str. 314. i 317.

42 Tekst Statuta o autonomiji Katalonije iz 2006. vidi na Generalitat de Catalunya na službenim web-stranicama na https://web. gencat.cat/en/generalitat/estatut/estatut2006/, odnosno na engleskom jeziku na https:/www.parlament.cat/document/ 
nih prigovora i političkih problema. Središnje španjolske vlasti bile su protiv priličnog broja pravnih rješenja iz novog Statuta. U to se uključio i Ustavni sud Španjolske te je 2010. godine u Odluci br. 31/2010. četrnaest članaka novog Statuta o katalonskoj autonomiji proglasio protuustavnima. ${ }^{43}$ Posebno se to odnosilo na novu formulaciju iz Preambule Statuta po kojoj se Katalonija definira kao „nacija“, uvođenje termina „nacionalni simboli“ te uzdizanje katalonskog jezika iznad španjolskog. Također je podsjetio da je Ustav Španjolske iz 1978. po hijerarhiji iznad Statuta o autonomiji Katalonije. Naime, Ustavni sud nije se protivio deklariranju katalonskog jezika „službenim jezikom u Kataloniji“, nego je prigovor imao na preferencijalni status katalonskog u odnosu na španjolski jezik, službeni u Španjolskoj. ${ }^{44}$ Naime, novi Zakon o jezičnoj politici (Llei de política lingüística iz 1998.) nametnuo je korištenje katalonskog jezika u svim značajnim socijalnim interakcijama, dajući mu preferencijalan tretman i u javnom i u privatnom sektoru, iako je istodobno zadržao individualno pravo uporabe i katalonskog i kastiljanskog. ${ }^{45}$ Razlog tomu preferencijalnom tretmanu činjenica je da katalonski jezik ne može parirati kastiljanskom ili, recimo, engleskom jeziku. ${ }^{46}$ Sve poduzete mjere jasno su ukazivale na to da je cilj katalonskih vlasti katalonski jezik učiniti „dominantnim jezikom“ u Kataloniji, odnosno razviti monolingvalno društvo. ${ }^{47}$ No, u godinama nakon donošenja tog Zakona, katalonska vlada ipak nije silom primjenjivala taj Zakon, prije se fokusirala na obrazovanje i pregovaranje oko implementacije. ${ }^{48}$ „Katalanizacija obrazovnog sustava“ dovela je do kontroverzi i onemogućila kastiljanskim govornicima (kojih je otprilike polovica stanovništva) da se educiraju na svojem prvom jeziku, pa je tako bila u suprotnosti s Ustavom iz 1978. godine. ${ }^{49}$

Političke stranke i veći dio katalonske javnosti bili su ogorčeni zbog reakcije Ustavnog suda. Predbacili su mu da je ispolitiziran i da ne poštuje glasače u Kataloniji koji su odobrili tekst Statuta i to na službenom referendumu. ${ }^{50} \mathrm{U}$ Barceloni su organizirane velike demonstracije $\mathrm{u}$ kojima je više od milijun ljudi izašlo na ulice. ${ }^{51}$ Slogan demonstracija bio je: „Mi smo nacija, mi odlučujemo" (Som una nació, nosaltres decidim.). Za dio Katalonaca ta je odluka Ustavnog suda „zatvorila vrata katalonskoj integraciji u španjolsku državu“ i dodatno osnažila secesioniste. ${ }^{52}$

cataleg/150259.pdf/.

Sentencia del Tribunal Constitucional sobre el Estatuto de Autonomía de Cataluña de 2006, 31/2010, e 28 de junio de 2010 , BOE-A-2010-11409.

Blanke, H.-J., and Abdelrehim, Y., Catalonia and the Right of Self-Determination from the Perspective of International Law, Max Planck Yearbook of United Nations Law Online, Brill, Vol. 18, No. 1, 2014, str. 542.

Carla, op. cit. (bilješka 38), str. 102.

Zakonom je također ojačana obveza da zaposleni u javnom sektoru znaju katalonski, koji je jedini jezik administracije katalonske vlade za komunikaciju s javnošću, iako je moguće tražiti informacije i na kastiljanskom. Zakon nadalje uključuje različite mjere promoviranja upotrebe katalonskog, npr. zahtjev za kvotama katalonskog jezika u masovnim medijima, obvezna uporaba katalonskih znakova u javnim i privatnim entitetima i kazne za one koji to krše. Time je taj Zakon napravio odmak od „edukacije prema promociji i regulaciji“. Ibidem str. 102. i autore koje navodi u bilješkama 49.-54. Ibidem, str. 102. O jezičnoj politici u Kataloniji detaljnije vidi u ibidem, str. 102.-105. Miley, T. J., The Constitutional Politics of Language Policy in Catalonia, Spain, Adalahs Newsletter, Vol. 29, October 2006, str. 2. Blanke and Abdelrehim, op. cit. (bilješka 44), str. 542. Rally in Catalonia Adds a Worry for Spain, September 11, 2012, na https://www.nytimes.com/2012/09/12/world/europe/12ihtbarcelona12.html/. 
Inače, od 2009. do 2011. godine u Kataloniji je organiziran niz neformalnih i neobvezujućih ispitivanja javnog mijenja - žele li neovisnost ili ne. Ti su referendumi neprestano uzburkavali javnost i obilježili politički život Katalonije, ali i cijele Španjolske. Novi val demonstracija kreće 11. rujna 2012. kada se dotada nezabilježen broj demonstranata, njih čak 1,5 milijuna, skupio u centru Barcelone pod sloganom „Katalonija, nova europska država“. ${ }^{53}$ Središnje španjolske vlasti odbijaju pregovore s Katalonijom o samostalnosti, a za posljedicu katalonske elite najavljuju izbore o neovisnosti za dvije godine. ${ }^{54}$

U siječnju 2013. godine katalonski Parlament usvojio je Deklaraciju o suverenosti i pravu na odlučivanje katalonskog naroda (Declaracio de Sobirania i del dret a decidir del poble de Catalunya), koja je pozvala na organiziranje referenduma najavljenog za 2014. godinu. ${ }^{55}$ Ustavni sud Španjolske tu je Deklaraciju proglasio neustavnom i ništavnom. ${ }^{56}$ I španjolski Parlament u travnju 2014. odbija prijedlog o održavanju referenduma o neovisnosti Katalonije. No, katalonske su vlasti u rujnu 2014. preformulirale zahtjev za referendumom i objavile da je referendum „neformalan“ $i$ time neobvezujući, odnosno da je u formi „konzultacija s narodom“. 57

Konačno je, nedugo nakon održavanja škotskog referenduma 9. studenog 2014. godine, proveden „neobvezatni i neformalni referendum“ o neovisnosti u Kataloniji. ${ }^{58}$ Organizatori referenduma postavili su dva pitanja: „žele li glasači da Katalonija postane država“ i „žele li da ta država bude neovisna“. Rezultati referenduma pokazali su da je 2,2 milijuna ljudi (oko 37 \% glasača) izašlo na izbore i od njih je $80 \%$ potvrdno odgovorilo na oba pitanja. ${ }^{59}$ Secesionistička elita bila je zadovoljna rezultatima, iako je izlaznost bila niža od očekivane. Kako je organiziranje referenduma u izričitoj nadležnosti španjolske Vlade, prema čl. 92. Ustava Španjolske, reakcije središnjih vlasti bile su jasne: referendum je protuustavan. Secesionisti su se i dalje branili argumentom da referendum „nikog ne obvezuje“ i da imaju pravo pitati narod što želi.

Točno godinu nakon što je organiziran neformalan referendum o neovisnosti u Kataloniji, 9. studenog 2015. katalonski Parlament održao je povijesno zasjedanje na kojem je održana debata te glasanje o postupku odcjepljenja od Španjolske. ${ }^{60}$ Katalonski Parlament odobrio je Deklaraciju o inicijaciji procesa neovisnosti Katalonije (Declaració d'inici del procés d'independència de Catalunya) s ne pretjerano uvjerljivom većinom: sedamdeset dva glasa za i šezdeset

53

„Huge Turnout for Catalan Independence Rally“, September 11, 2012, na https://www.bbc.co.uk/news/world-europe-19564640/.

Gonzales, C., The Catalan National Identity and Catalonia's Bid for Independence, Connecticut Journal of International Law, Vol. 32, No. 2, 2016, str. 126.-127.

Resolució 5/X del Parlament de Catalunya, per la qual s'aprova la Declaració de Sobirania i del dret a decidir del poble de Catalunya, Tram. 250-00059/10 i 250-00060/10, Parlament de Catalunya (2013), na službenim mrežnim stranicama Parlamenta Katalonije na https://www.parlament.cat/document/intrade/7094/.

56 Sentencia 42/2014, de 25 de marzo BOE (Official State Gazzete) number 87, of 10 April 2014, https://ep00.epimg.net/ descargables/2014/03/25/d10fedeef8013087d218afcd11cf9ebf.pdf?rel=mas/.

57 „Spanish court suspends Catalonia independence vote“, September 29, 2014, na https://www.reuters.com/article/us-spaincatalonia-court/spanish-court-suspends-catalonia-independence-vote-idUSKCNOHO1XB20140929/. „Catalonia Cancels Vote to Secede From Spain, but Calls for Nonbinding Ballot“, October 14, 2014, na https://www.nytimes.com/2014/10/15/world/ europe/catalonia-cancels-referendum-on-independence-in-november.html/.

8 „Catalonia Vote: 80\% Back Independence-Officials“, November 10, 2014, nahttp://www.bbc.com/news/world-europe-29982960/. Ibidem.

„Catalan Parliament Passes Motion Declaring Start of Secession Process“, November 9, 2015, na https://elpais.com/ elpais/2015/11/09/inenglish/1447067955_007589.html/. Catalonia MPs Vote for Secession as Spain Looks to Block Plans in Court, November 9, 2015, na https://www.theguardian.com/world/2015/nov/09/catalonia-mps-to-vote-on-secession-plan-inshowdown-with-spains-government/. 
tri protiv ${ }^{61}$ Deklaracija, iako kratka, bila je prilično ambciozna. U njoj se deklarira „početak procesa kreiranja neovisne katalonske države u formi republike“. Također se poziva Parlament da započne s procesom pripreme zakona kojim bi se kreirao neovisan sustav socijalne sigurnosti i poreznih vlasti. ${ }^{62}$ U Deklaraciji je navedeno da Parlament i proces demokratskog odvajanja neće biti predmetom odluka institucija španjolske Vlade, posebno ne odluka Ustavnog suda Španjolske. ${ }^{63}$ Ustavni je sud, prema Deklaraciji, „delegitimiziran“ i bez nadležnosti zbog Odluke iz lipnja 2010. o protuustavnosti određenih odredbi novog Statuta o autonomiji Katalonije iz 2005. godine. ${ }^{64}$

Na proslavi Katalonskog nacionalnog dana, 11. rujna 2015., ponovno je organiziran masovni prosvjedni skup na kojem je sudjelovalo od 1,5 do 2 milijuna ljudi, a skup je obilježen emotivnim prosecesionističkim govorima. ${ }^{65} \mathrm{U}$ međuvremenu, na regionalnim izborima krajem rujna 2015. godine, secesionisti su dobili apsolutnu većinu (72 od 135 zastupničkih mjesta). ${ }^{66}$ Time su dobili snažan vjetar u leđa te objavili da im pobjeda na izborima za katalonski Parlament daje ,jasan mandat da formiraju neovisnu katalonsku državu“ ${ }^{67}$

\subsection{REFERENDUM O NEOVISNOSTI (2017.) I UVOĐENJE PRINUDNE UPRAVE U KATALONIJI}

Dana 9. lipnja 2017. katalonski predsjednik Carlos Puigdemont najavljuje novi referendum o neovisnosti za 1. listopada. Ako pobjede, pristaše secesionizma i neovisnosti za 48 sati od referenduma proglasit će neovisnu Republiku Kataloniju, i to bez obzira na izlaznost. Referendum je održan 1. listopada 2017. i na njega je, navodno, izašlo 2,25 milijuna birača od 5,3 milijuna registriranih birača od kojih je, njih navodno, 90 \% glasalo za neovisnost. ${ }^{68}$ No, činjenica je da su referendum uglavnom bojkotirali protivnici secesionizma, stoga više od pola glasača nije ni glasalo. ${ }^{69}$

Ono što je zateklo europsku i svjetsku javnost, bile su reakcije središnjih vlasti na referendum. Naime neočekivano je došlo do sukoba između policije (ne katalonske, nego iz drugih dijelova Španjolske) i katalonskih glasača i cijeli je dan bio kaotičan u Kataloniji. Kako bi onemogućili referendum, španjolski policajci upotrijebili su gumene metke i pendreke i doslovno

\footnotetext{
61 Ibidem.

62 Gonzales, op. cit. (bilješka 54), str. 131.

63 Ibidem.

64 Ibidem.

65 „Catalan Independence Rally Draws Crowds in Barcelona“, September 11, 2015, na https://www.bbc.com/news/worldeurope-34219386/.

66 „Catalonia Vote: Pro-independence Parties Win Elections“, September 28, 2015, https://www.bbc.com/news/worldeurope-34372548/.

67 Ibidem.

68 „Catalonia Independence Referendum: What Just Happened?“, October 2, 2017, na https://edition.cnn.com/2017/10/02/ europe/catalonia-independence-referendum-explainer/index.html/.

69 „Crisis in Catalonia: The Independence Vote and Its Fallout“, September 26, 2017, na https://www.nytimes.com/2017/09/26/ world/europe/spain-catalonia-referendum.html/.
} 
onemogućili fizički izlazak katalonskim glasačima na glasačka mjesta. Također su oduzimani izborni leci i listići te je oduzet i dio glasačkih kutija. Rušen je i elektronički sustav glasova, pa je, u konačnici, zapravo bilo nemoguće dati ni približno točnu informaciju o rezultatima referenduma. ${ }^{70}$ Tako je referendum, ustvari, propao. U konačnici, prema podacima Odjela za zdravlje Katalonije, više od osamsto Katalonaca zatražilo je liječničku pomoć zbog ozljeda nanesenih tijekom toga dana. ${ }^{71}$

I međunarodne nevladine organizacije upozorile su Španjolsku zbog kršenja ljudskih prava u Kataloniji u vezi s organiziranjem i provedbom referenduma u listopadu 2017. godine. Primjerice, Human Rights Watch Španjolskoj je predbacio ekstenzivnu upotrebu sile od strane sigurnosnih snaga (civilne garde ili nacionalne policije). ${ }^{72}$ Bilo je jasno da su upotrijebili, tvrdi HRW, nasilje protiv mirnih prosvjednika. U vezi s kršenjem ljudskih prava u Kataloniji, Amnesty International također je prigovorio Španjolskoj kršenje „prava na izražavanje“ i „prava na mirno okupljanje“ pristaša katalonske neovisnosti, odnosno da su bili neproporcionalno ograničeni. U Izvještaju za 2017./18. Amnesty International navodi da su španjolske snage sigurnosti rabile prekomjernu silu protiv demonstranata koji su mirno prosvjedovali 1. listopada. ${ }^{73} \mathrm{U}$ veljači 2018. godine Amnesty je upozorio španjolske vlasti i na predugo držanje Jordi Sancheza, bivšeg predsjednika organiziranja pokreta za neovisnost Katalonije, u pritvoru. ${ }^{74}$ Po mišljenju Amnesty Internationala, privatne osobe i predsjednici organizacija civilnog društva imaju pravo izraziti mišljenje suprotno odluci Ustavnog suda, kao i organizirati mirno okupljanje kao podršku referendumu za katalonsku neovisnost. ${ }^{75}$

Puigdemont je na neki način proglasio neovisnost 10. listopada 2017., a središnje su vlasti tražile da se i službeno očituje je li to učinio. ${ }^{76}$ Tada je katalonski Parlament službeno glasao za neovisnost. ${ }^{77}$ Naime, 27. listopada donesena je Rezolucija kojom je „stvorena katalonska Republika kao neovisna država, suverena i legalna država“". ${ }^{78}$ Nedugo nakon glasanja regionalnog parlamenta, španjolski Parlament donio je odluku bez presedana kojom se španjolskoj

70 "Catalan Referendum: Preliminary Results Show 90\% in Favour of Independence“, October 2, 2017, na https://www.theguardian. com/world/2017/oct/01/dozens-injured-as-riot-police-storm-catalan-ref-polling-stations/.

71 Ibidem.

72 „Spain: Police Used Excessive Force in Catalonia Hold Independent Investigation into Violence During Referendum“, Human Rights Watch, October 12, 2017, na https://www.hrw.org/news/2017/10/12/spain-police-used-excessive-force-catalonia. Vidi, također, Human Rights Watch - Spain, na https://www.hrw.org/europe/central-asia/spain/.

73 Amnesty International - Spain 2017/2018, na https://www.amnesty.org/en/countries/europe-and-central-asia/spain/reportspain/. Također, javna izjava Amnesty Internationala o događanjima 1. listopada 2017. na https://www.amnesty.org/download/ Documents/EUR4174732017ENGLISH.pdf/.

Iako države imaju pravo uvesti neka ograničenja ostvarenja prava na slobodu izražavanja zbog određenih pravnih razloga, takva zaštita ,javnog poretka“ ili „nacionalne sigurnosti“ zahtijeva da vlasti pokažu kako su takva ograničenja neophodna i proporcionalna ciljevima države. Optužbe o ozbiljnim kaznenim djelima protiv organizatora takvih sastanka čini se „prekomjerno i nesrazmjerno“. „Spain: Ongoing Detention of Jordi Sanchez is Excessive and Disproportionate”, February 6, 2018, na https:// www.amnesty.org/en/latest/news/2018/02/spain-ongoing-detention-of-jordi-sanchez-is-excessive-and-disproportionate/

75 Ibidem.

76 „Crisis in Catalonia: The Independence Vote and Its Fallout“, loc. cit. (bilješka 69).

77 Ibidem.

78 Rezolucija kojom je proglašena neovisnost prihvaćena je sa sedamdeset glasova za, deset protiv i dva suzdržana u parlamentu koji ima 135 zastupničkih mjesta. „Catalans Declare Independence as Madrid Imposes Direct Rule“, October 27, 2017, na https://www.bbc.com/news/world-europe-41780116/. 
Vladi dopušta uvođenje direktne uprave nad Katalonijom. ${ }^{79}$ Španjolski premijer na temelju toga hitno proglašava izvanredne mjere u skladu s čl. 155. Ustava. Taj se članak aktivira prvi put u španjolskoj povijesti. Riječ je o slučajevima „propuštanja ispunjenja obveza koje proizlaze iz Ustava ili drugih zakona“, odnosno ako regionalne vlasti „djeluju na način da ozbiljno ugroze opće interese Španjolske“. Primjenom tog članka, španjolske vlasti poduzele su oštre političke i administrativne mjere kontrole regije i time uvele direktnu upravu nad Katalonijom. ${ }^{80} \mathrm{U}$ izrazito napetoj i mučnoj atmosferi raspušta se katalonska Vlada i najavljuju novi parlamentarni izbori za regionalni katalonski Parlament. Osim toga, krenula su i najavljena uhićenja lidera secesionističkog pokreta zbog „pobune protiv države“ ${ }^{81}$ Španjolski državni odvjetnik zatražio je, naime, progon dvadesetak katalonskih političara zbog pobune, nasilja te pronevjere i zloupotrebe javnih fondova u vezi s organiziranjem protupravnog referenduma za neovisnost. ${ }^{82}$ Pod prijetnjom uhićenja, Puigdemont i određeni suradnici bježe u Belgiju. $^{83}$

Španjolske vlasti odlučile su pokazati namjeru vraćanja kontrole katalonskim političarima u nadi da će secesionistički pokret oslabiti i da će se učvrstiti veze Katalonije s Madridom. No, indikativno, rezultati novih regionalnih izbora pokazali su još jednu u nizu pobjeda secesionističkih snaga. Secesionisti su, naime, osvojili 47 \% glasova, odnosno dobili 70 od 135 mjesta u katalonskom Parlamentu. ${ }^{84}$ To su samo za dva zastupnika manje od prethodnih izbora za katalonski Parlament 2015. godine. ${ }^{85}$ Protivnici neovisnosti dobili su najveći broj zastupničkih mjesta od svih stranaka, no ne i dovoljan da formiraju Vladu. ${ }^{86}$

Sva ta događanja teško su narušila već osjetljive odnose između Španjolske i Katalonije, a užarena retorika obiju strana i odbijanje kompromisa i pregovora, nastave li se, mogu odvesti do nasilja nezabilježenog u modernoj povijesti zapadne Europe. Španjolske vlasti očito se teško nose s najvećom političkom i ustavnom krizom u državi od uvođenja demokracije krajem 70-ih godina. Direktna vladavina Madrida, naime, nastavila se od listopada 2017. do lipnja 2018. kada su Katalonci konačno ponovo uspostavili kontrolu nad Katalonijom. Nakon sedmomjesečne direktne uprave Madrida, nova katalonska Vlada na čelu s Quimom Torrom preuzela je regionalnu vlast početkom lipnja 2018. godine. ${ }^{87}$

\footnotetext{
79 Odluka je prošla sa 214 glasova za i 47 glasova protiv. Ibidem.

80 „Crisis in Catalonia: The Independence Vote and Its Fallout“, loc. cit. (bilješka 69).

81 Ibidem.

82 Ibidem.

83 Španjolska je poslije, 19. lipnja 2018., povukla uhidbeni nalog za njega i još petoricu separatističkih vođa.

84 Uspjeh secesionističkih stranaka ostvaren je i bez obzira na to što je katalonski predsjednik Carles Puigdemont kampanju vodio u egzilu u Belgiji, dok je nekoliko secesionističkih političara pritvoreno. „Catalonia’s Bid for Independence from Spain Explained“, January 31, 2018, na https://www.bbc.com/news/world-europe-29478415/.

85 Trebaju 68 glasova da bi imali većinu od 135 zastupničkih mjesta. Ibidem.

86 Stranka premijera Rayoya, Narodna stranka (Partido Popular), pala je dramatično u broju zastupničkih mjesta s jedanaest na tri. „Separatist Parties in Spain's Catalonia Win Majority in Election“, December 22, 2017, https://edition.cnn.com/2017/12/21/ europe/catalonia-election-results-independence-spain-intl/index.html/.

87 „Catalonia: Madrid's Direct Rule Ends with New Catalan Government“, June 2, 2018, na https://www.bbc.com/news/worldeurope-44342610/.
} 
Katalonija je danas multietnička regija, što ima veze s relativnim bogatstvom regije od 18. st., ali i pristupačnošću s kopna i mora, što je ojačalo imigraciju i miješanje stanovništva. ${ }^{88}$ Zadnji najveći val imigracije zbio se u doba Francove ere, kada je Katalonija primila više od milijun ljudi iz drugih dijelova Španjolske. ${ }^{89}$ Danas u Kataloniji živi oko sto sedamdeset nacionalnosti i govori se preko tristo jezika. ${ }^{90}$ Katalonija je jaka industrijalizirana regija i ima, smatraju neki, jednu od najvećih stupnjeva autonomije u svijetu. ${ }^{91}$ No, Katalonija nema kontrolu nad prihodima iz poreza i plaća vrlo visok iznos središnjim vlastima. Katalonci smatraju da ih „Madrid potkrada“ (Madrid nos roba), jer se samo manji dio tih prihoda vraća u Kataloniju. Naime, Generalitet nema punu fiskalnu autonomiju, u prvom redu moć prikupljanja poreza, i uglavnom se oslanja na „financijski transfer od središnjih vlasti“ ${ }^{92}$

Upravo tu činjenicu secesionisti rabe kao jedan od ključnih razloga za odcjepljenje od Španjolske. Drugi je ključan razlog da se vlasti u Madridu teško nose s krizom u eurozoni, a secesionisti smatraju da bi se Katalonija kao samostalna država lakše i uspješnije nosila s posljedicama ekonomske krize. Od 2007. godine Španjolsku je vrlo teško pogodila ekonomska kriza: ima drugu najveću stopu nezaposlenosti u EU-u s 20,4 \% 2010. godine, a nezaposlenost mladih dosegla je 43,5 \% na kraju 2009., što je povećanje od 24 \% od kraja 2007. godine. ${ }^{93}$ Nezaposlenost u Kataloniji iznosi približno 16,53 \%, a najveća je među mlađima od 24 godine (41,2 \%) i niže kvalificiranima. ${ }^{94}$ Prema statističkim podacima iz 2017. godine BDP u Kataloniji čini otprilike petinu španjolskog BDP-a, s time da je najniži postotak udjela Katalonije bio 2009. godine (19 \% španjolskog BDP-a). ${ }^{95}$ Time je Katalonija glavni prinosnik španjolskoj ekonomiji, a GDP po glavi stanovnika viši je od prosjeka EU-a. ${ }^{96}$

Kako god, poslovni svijet tradicionalno izbjegava rizike i s manje turbulentnim političkim sredinama od onih koje sa sobom nosi secesionizam. Kao u škotskom slučaju, jasno je da u slučaju odcjepljenja dio španjolskog duga na sebe mora preuzeti i neka buduća Katalonija, što bi dodatno otežalo ekonomsku stabilnost novoformirane države. Gubitak sigurnog tržišta (matične države) za plasman roba i usluge, snažno potresa ekonomiju novoformirane države. Gotovo će sigurno doći do pada standarda i moguće (nove) ekonomske krize. Španjolska osigurava Kataloniji sigurno i veliko domaće tržište, stabilniju valutu, pristup europskim fon-

88 Scotoni, P.P. I, Exercising Self-Determination without Jeopardising the Rights of the Others: The Catalan Model, St. Thomas Law Review, Vol 14, No. 2, 2001, str. 398.

89 Ibidem.

90 Climent-Ferrando, V., Immigration in Catalonia, in Search of a Public Philosophy, Interdisciplinary Research Group on Immigration (GRITIM - UPF), Universitat Pompeu Fabra, Barcelona, 2012, str. 3. O migracijama u Kataloniju i rastu stanovništva vidi ibidem, str. 7. i dalje.

91 O poslijeratnom procesu političke decentralizacije u nekoliko zapadnoeuropskih država vidi Hopkins, J., The Future of SubNational Governments in a Supra-National World - Lessons from the European Union, Victoria University of Wellington Law Review, Vol 38, No. 1, 2007, str. 19. i dalje.

Slično drugim autonomnim zajednicama, izuzev Baskije i Navarre, koje imaju određeni stupanj autonomije nad prikupljanjem i managementom poreza. Carla, op. cit. (bilješka 38), str. 101. i bilješka 44.

93 Review of Higher Education in Regional and City Development 2008-10: Catalonia, Spain, The Organisation for Economic Cooperation and Development, 2010, str. 15.-16.

94 Ibidem, str. 16.

95 Statista, The Statistics Portal, na https:/www.statista.com/statistics/327063/gross-domestic-product-in-catalonia-and-spain/. 
dovima i slično. Secesija od Španjolske značila bi i gubitak eura kao službene valute. ${ }^{97}$ Nova valuta u Kataloniji donijela bi financijsku nestabilnost, moguću inflaciju i odvela u financijsku krizu. Ta bi kriza za posljedicu imala povlačenje investitora i premještanje sjedišta postojećih korporacija u druge dijelove Španjolske i unutar eurozone. Katalonija bi napuštanjem EU-a sigurno izgubila na BDP-u i povećala bi se nezaposlenost. Primjerice, prema statističkim podacima za prošlu, 2017. godinu BDP po glavi stanovnika u Kataloniji iznosio je 31.223 eura, u Španjolskoj 25.000 eura, a u EU-u 29.900 eura. ${ }^{98}$ Upravo je to razlog zbog kojeg Kataloniju neki smatraju najdinamičnijom španjolskom regijom koja je dugo trpjela centralizaciju i političku represiju i u kojem se društvu politički glas Katalonaca čuo neproporcionalno u odnosu na brojnost stanovništva i ekonomsku snagu Katalonije. ${ }^{99}$ Španjolska bi ostala unutar EU-a pa bi vjerojatno imala snažn(ij)u podršku međunarodnih i regionalnih institucija da stabilizira ekonomiju u slučaju secesije. S druge strane, tim mogućim ekonomskim potresima ne treba prijetiti. Bookman naglašava da se treba voditi računa o tome da se minimiziraju negativni efekti na ekonomije obiju strana: i postojeće države i one nastale secesijom ${ }^{100}$. Iako je realno očekivati da bi odcjepljenje ostavilo dramatične ekonomske posljedice i na Kataloniju i na ostatak Španjolske, ne znači da ekonomski ne bi preživjeli i jedni i drugi.

\section{KOMPARACIJA SECESIONISTIČKIH ZAHTJEVA U KATALONIJI I ŠKOTSKOJ}

\subsection{KRATAK POVIJESNI PRIKAZ ŠKOTSKIH ZAHTJEVA ZA NEOVISNOST}

U ovom dijelu nećemo detaljno prikazati proces razvoja škotskog secesionizma i puta prema neovisnosti, nego ćemo se koncentrirati na najnovija događanja i odnos škotskih secesionista s vlastima UK-a. Povijest Škotske stara je i vuče korijene od 9. st., a već od 13. st. obilježena je sukobima s moćnim susjedima, posebno Englezima. Početkom 17. st. Škotska i Engleska ulaze u kratku personalnu uniju, da bi početkom 18. st. ušle i u formalnu uniju dvaju kraljevstava. Škotska je do 1707. godine bila neovisna da bi te godine škotski Parlament potpisao poseban Ugovor o uniji s Engleskom. ${ }^{101}$ Time je prestao postojati škotski Parlament i vlast se u cijelosti preselila u London. Bio je to, kako su Škoti znali reći, „zadnji dan Škotske - kao

97 Preostale bi im dvije varijante: a) uvesti svoju valutu ili b) pridružiti se klubu europskih država koje nisu članice EU-a, a imaju euro kao službenu valutu (npr. San Marino, Vatikan, Andora i Lichtenstein; Kosovo i Crna Gora rabe euro kao službenu bez sporazuma s EU-om i pristupa Europskoj središnjoj banci). Drugo je izglednije, no s bitno manje zaštite u odnosu na onu koju pruža Europska središnja banka prema državama-članicama EU-a.

98 Idescat, Source Catalonia, Spain, Eurozone and European Union: Eurostat. Official Statistics Website of Catalonia, Generalitat de Catalunya, July 18, 2018, na https://www.idescat.cat/indicadors/?id=ue\&n=10131\&lang=en/.

99 Ehrlich, op. cit. (bilješka 10), str. 301.

100 Vidi detaljnije Bookman, M., The Economics of Secession, St. Martin's Press, New York, 1992, str. 69.-70.

101 Godine 1800. nastaje Ujedinjeno Kraljevstvo Velike Britanije i Irske na temelju Zakona o uniji, kojim su se ujedinile Velika Britanija i Irska. Poslije će se veći dio Irske odvojiti i 1922. godine formirati Republiku Irsku. Ostatak Sjeverne Irske formirat će Ujedinjeno Kraljevstvo Velike Britanije i Sjeverne Irske. Za razliku od većine Iraca koji su se u 20. st. uspjeli osloboditi engleske dominacije, Škoti nisu bili dovoljno organizirani niti su imali razvijenu političku svijest dovoljnu za samostalnost. 
Škotske“. ${ }^{102}$ Otada traje nezadovoljstvo i otpor Škota protiv takvog političko-pravnog rješenja odnosa s moćnim susjedima na Otoku. Val škotskog nacionalizma razvijao se od sredine 19. st., no, kao i u Kataloniji, tek će šezdesetih godina 20. st. biti jasno politički formuliran i uključivati pozive na neovisnost. Početak snažne dekolonizacije, sve glasnija pozivanja na samoodređenje kolonijalnih naroda, jačanje regionalizma i nacionalističke retorike, zahvatili su i škotske nacionaliste. Njihove ambicije počinju rasti. U političkom smislu, ključna je Škotska nacionalna stranka, najjača prosecesionistička stranka u Škotskoj, osnovana između dva svjetska rata. U Parlament ulazi krajem 60 -ih. ${ }^{103}$ Drugi važan trenutak za škotske secesioniste otkriće je naftnih izvora u Sjevernom moru blizu škotske obale. ${ }^{104}$

\subsection{REFERENDUMI O USPOSTAVI PARLAMENTA ŠKOTSKE (1979. I 1997.) I SPORAZUM IZ EDINBURGA (2012.)}

Prvi referendum u Škotskoj, povezan s jačanjem škotskog regionalizma, organiziran je 1979. godine s ciljem uspostave samostalnog škotskog parlamenta. Uvjet za referendum bio je da 40 \% ukupnog broja glasača mora glasati „za“ da bi rezultati i promjene bili prihvaćeni. Kako je „za“ glasalo 52 \% glasača (48 \% bilo je protiv), a izašlo samo 64 \% glasača, proizašlo je da je samo 32,9\% glasača dalo svoj glas. Uvjet je bio da barem $40 \%$ glasača da svoj glas. ${ }^{105} \mathrm{Ne}-$ zadovoljnici su to pravilo o $40 \%$ smatrali nepravednim i nedemokratskim. Pokušaj osnivanja parlamenta tako je propao.

Drugi referendum i drugi pokušaj osnivanja škotskog parlamenta organiziran je osamnaest godina poslije, 1997., i to nakon pažljivih priprema. Rezultati su pokazali da je 74,3 \% glasača bilo „za“ formiranje parlamenta (izlaznost 44,8 \% biračkog tijela), ${ }^{106}$ bitno više u odnosu na 52 $\%$ potvrdnih glasova na referendumu iz 1979. Parlament u Londonu potvrdio je Zakon o Škotskoj 1998. godine i time je formiran škotski Parlament. Godine 1999. održani su prvi izbori za škotski Parlament i nedugo nakon toga održano je prvo zasjedanje škotskog Parlamenta nakon 1707. godine. Škotski Parlament u nadležnost je dobio agrikulturu, zdravlje, obrazovanje, transport, lokalnu (samo)upravu, pravo, socijalni rad, stanovanje, turizam i ekonomski razvoj, sport i umjetnost. Sva druga pitanja u nadležnosti su Parlamenta u Westminsteru (npr. obrana, vanjska politika, imigracija itd.).

Kada je 2011. godine na izborima pobijedila SNP, neovisnost Škotske od UK-a postala je udarna tema u britanskim medijima i šire. Sporazumom iz Edinburgha (15. listopada 2012.), britanske vlasti dopustile su škotskom Parlamentu da održi referendum o secesiji do kraja

\footnotetext{
102 Connolly, op. cit. (bilješka 12), str. 60.

103 Ibidem.

104 Ibidem.

105 Dewdney, R. Results of Devolution Referendums (1979 \& 1997), Research Paper no. 97/113, 10 November 1997, Social and General Statistics Section, House of Commons, Library.

106 Ibidem. O razvoju devolucije unutar unitarnog UK-a detaljnije vidi Tierney, S., Giving with One Hand: Scottish Devolution within a Unitary State (u daljnjem tekstu: „Thierney: Giving with one Hand“), International Journal of Constitutional Law, Vol. 5, No. 4, 2007, str. 730. i dalje.
} 
2014. godine. ${ }^{107}$ Odobrila su ga oba doma britanskog Parlamenta. Time je referendum o secesiji i neovisnosti Škotske legaliziran i prvi put u skladu s britanskim propisima. Sporazumom su, također, utvrđena pravila i procedure za održavanje referenduma o neovisnosti Škotske. Odlučeno je da će glasači dobiti pitanje: “Treba li Škotska postati neovisna država?", a ponuđena su bila dva odgovora: „Da“ ili „Ne“. ${ }^{108}$ Englezi ni jednom gestom nisu željeli ugroziti škotsko pravo na referendum iako, naravno, nisu tajili da su protiv škotske secesije te su otvoreno agitirali za ostanak Škotske u Uniji. Središnje britanske vlasti na čelu s Cameronom bile su samouvjerene u pobjedu. Dana 18. rujna 2014. godine građani su izašli na birališta i rezultati su pokazali da Škotska ostaje unutar UK-a, na veliko razočaranje prosecesionističkih stranaka i glasača. ${ }^{109} \mathrm{Od}$ $84 \%$ glasača, što je iznimno visoka izlaznost, 55,3 \% glasača izrazilo je želju za ostankom u UK-u, dok je 44,7 \% željelo neovisnu Škotsku. ${ }^{110}$

Škotska se u literaturi često navodi kao praktičan primjer „građanskog više nego etničkog nacionalizma“, jer dosada konvencionalne kulturne karakteristike i različitosti (npr. jezik ili vjera) nisu toliko tipične za Škote kao nešto što ih bitno razlikuje od dominantnih Engleza. ${ }^{111}$ Ti tradicionalni kulturni argumenti marginalni su u nacionalističkom diskursu u slučaju Škotske. ${ }^{112}$ Prema službenim podacima 2011. godine, $83 \%$ populacije Škotske osjeća da ima neki oblik „škotskog nacionalnog identiteta“, dok se 62 \% smatra „Škotima“, 18 \% ima dvostruki identitet - škotski i britanski, dok samo britanski identitet ima 8 \% stanovništva. ${ }^{113}$ Škotima se smatra 84 \% ljudi. Danas u Škotskoj 98,6 \% građana govori engleskim jezikom. Od 18. st. razvio se, kao kombinacija škotskog i engleskog, i jedinstveni dijalekt poznat kao „škotski engleski“. Drugi jezik koji se govori u Škotskoj jest „škotski“ i njega govori otprilike trećina Škota (30 \%). ${ }^{114}$ Treći jezik u Škotskoj jest „škotski galski“ koji je danas ugrožen jer ga govori oko 1,1 \% škotskog stanovništva. ${ }^{115}$

Više je razloga pobjede protivnika škotske secesije u UK-u. U prvom redu, nemali broj Škota smatra se Britancima, dio njih ,jednako Škotima i Britancima“, a možda samo četvrtina „Škotima i ne-Britancima“. ${ }^{116}$ Znatan broj njih živi i radi u dijelovima UK-a izvan Škotske.

107 Connolly, op. cit. (bilješka 12), str. 62 . O pregovorima koji su prethodili Sporazumu iz Edinburgha i pripremama za Referendum 2014. detaljnije vidi Tierney, S., Legal Issues Surrounding the Referendum on Independence for Scotland (u daljnjem tekstu: „Tierney, Legal issues Surrounding the Referendum on Indepedence for Scotland“), European Constitutional Law Review, Vol. 9, No. 3, 2013, str. 359. i dalje.

108 O problematici formulacije referendumskih pitanja o neovisnosti vidi detaljnije Vidmar, J.,The Scottish Independence Referendum in an International Context, The Canadian Yearbook of International Law, Vol. 51, 2013, str. 261. i dalje.

109 “Scottish Referendum: Scotland Votes 'No' to Independence”, September 19, 2014, https://www.bbc.co.uk/news/uk-29223984/.

110 Ibidem.

111 Nakon Unije Škotske i Engleske, škotski je identitet prevladao. Iako je Škotska postala dio UK-a, nikad nije postala „Sjeverna Britanija“. Iako nema odvojene jezične kulture, postoji jak škotski identitet. Vidi Jerve, Eivind, Explaining Scottish and Catalan Secessionist Mobilization in the Framework of the EU, master thesis, Department of Comparative Politics University of Bergen, Spring 2015, str. 61. i autore koje navodi.

112 Ibidem, str. 97.

113 Scotland's Census, The National Records of Scotland, Crown copyright, 2014 na https://www.scotlandscensus.gov.uk/ods-web/ area.html/.

114 Ibidem. O jezicima u Škotskoj detaljnije vidi Nihtinen, A.L.K, Scotland's Linguistic Past and Present: Paradoxes and Consequences, Studia Celtica Fennica, Vol. 2, 2005, str. 118. i dalje.

115 Scotland's Census, The National Records of Scotland, loc. cit. (bilješka 113).

116 „Scotland votes 'No': How the 'No' Side Won the Referendum“, na https://www.bbc.com/news/uk-29223984/. 
Središnje britanske vlasti vrlo su pažljivo pripremile popis promjena koje bi secesija izazvala u Škotskoj i to je unijelo strah i nemir u dovoljan broj glasača.

Deseci tisuća ljudi svakodnevno putuju u Škotsku na posao i natrag. Izlazak Škotske iz EU-a i Schengena uključivao bi gubitak EU-ova državljanstva, a sve bi to bitno i dramatično zakompliciralo život većini Škota. ${ }^{117}$ Čitav je niz situacija koje bi u slučaju odcjepljenja bile negativno obilježene u financijskom smislu. ${ }^{118}$ Jedna od posebno spornih pregovaračkih točki bila je britanska funta koje se Škoti nisu htjeli odreći. No, London je jasno upozorio da im neće ostaviti funtu kao službenu valutu. Škotska bi izgubila sigurno tržište za plasman robe i usluga u ostatku UK-a, kamo većinom i izvozi. Britanija je visoko razvijena demokratska država, ima međunarodni utjecaj, financijsku sigurnost, dobar mirovinski sustav, vodeća je država u svijetu znanosti, sporta i kulture, ima tradicionalno jak obrambeni sustav itd.

Poruka „It'll cost you!“ bila je dovoljna da dobar dio škotskih glasača odvrati od ideje o neovisnosti jer „svaka nacija ima svoju cijenu“.119 Sa sloganom „Škotska je jača u UK-u“, ali i „UK je jači sa Škotskom u njoj“, pobijedili su bez teškoća. ${ }^{120}$ Iako, o tome bi li Škoti secesijom profitirali ili izgubili u ekonomskom smislu, teško je reći s obzirom na brojne varijable. ${ }^{121} \mathrm{Za}$ govornici ostanka u Uniji bili su puno pozitivniji u kampanji i isticali samo pozitivne strane njihova povijesnog savezništva. Također, prevagu su odnijeli i stariji glasači koji su tradicionalno protiv odcjepljenja: imali su averziju od rizika i strah od nepoznatog, pa su glasali protiv, zadržavajući status quo. ${ }^{122}$

Na kraju, moramo se osvrnuti na još jedan važan događaj u UK-u. Ono što je bitno zakompliciralo situaciju u vezi budućnosti Škotske jest najava izlaska UK-a iz EU-a. Referendum o izlasku UK-a iz EU-a održan je 23. lipnja 2016. godine i rezultati su bili dramatični: 51,9 \% za izlazak i 48,1 \% za ostanak u EU-u. ${ }^{123}$ Izlaznost je bila visoka - 71,8\% ljudi (više od 30 milijuna glasača). ${ }^{124}$ Indikativno, Engleska i Wales su glasali za izlazak iz EU-a, a Škotska i Sjeverna Irska izrazili su želju za ostankom u EU-u. Naime, u Škotskoj je čak 62 \% glasača glasalo za ostanak unutar EU-a. ${ }^{125}$ Kao veliki pristaše EU-a, škotski secesionisti uzeli su rezultate ovog referenduma kao važan argument da se Škotska mora odcijepiti od UK i postati članicom EU-

117 O mogućim rješenjim prava na državljanstvo u kontekstu neke buduće neovisne Škotske i odnosima između UK i EU-a po tom pitanju vidi detaljnije Shaw, J., Unions and Citizens: Membership Status and Political Rights in Scotland, the UK and the EU, u: Closa, C., (ed.) Secession from a member state and Withdrawal from the European Union - Troubled Membership, Cambridge Universtiy Press, 2017, str. 153. i dalje.

118 „Scottish Independence Referendum“, UK Government Services and Information, https://www.gov.uk/government/topicalevents/scottish-independence-referendum/about/.

119 „Scottish Independence - It’ll Cost You“, April 14, 2012, na https://www.economist.com/leaders/2012/04/14/itll-cost-you/.

120 Scotland votes 'No': How the 'No' Side Won the Referendum, loc. cit. (bilješka 116). O škotskom referendumu za neovisnost i pravnim pitanjima i legalnosti, vidi detaljnije Armstrong, K., The Reach and Resources of European Law in the Scottish Independence Referendum, u: Closa, C., (ed.) Secession from a member state and Withdrawal from the European Union - Troubled Membership, Cambridge Universtiy Press, 2017, str. 106. i dalje.

121 Ibidem.

122 Perry, F. V. and Rehman, S., Secession, the Rule of Law and the European Union, Connecticut Journal of International Law, Vol. 31, No. 1, 2015, str. 63.

123 „Brexit: All you need to know about the UK leaving the EU“, November 5, 2018 na https://www.bbc.com/news/ukpolitics-32810887/.

124 Ibidem.

125 Ibidem. 
a. Bilo je i ideja da ukoliko UK izađe iz EU-a da bi Škotska mogla „naslijediti“ članstvo UK-a u EU-u, što je pravno i politički nemoguće. U svakom slučaju, Škotska bi htjela zadržati vezu s EU-om nakon Brexita. Situacija u UK-u je tako jedinstva, jer se čak dvije unije izaziva i propituje u isto vrijeme: tri stoljeća staru Uniju između Škotske i Engleske i četrdesetak godina staru uniju između UK-a i Europske zajednice/EU-a. ${ }^{126}$ Zahtjevi da se održi novi referendum o škotskoj neovisnosti u svjetlu Brexita britanske su vlasti odbacile. Britanska premijerka Theresa May poručila je Škotskoj „da sada nije vrijeme“ razgovarati o neovisnosti Škotske i da bi država trebala „sada raditi zajedno, a ne se razdvajati“. ${ }^{127}$ Iako su UK i EU započeli dvogodišnje pregovore oko izlaska UK-a iz članstva, do kraja 2018. ništa se bitno nije dogovorilo.

\subsection{SLIČNOSTI I RAZLIKE KATALONSKIH I ŠKOTSKIH ZAHTJEVA ZA NEOVISNOŠĆU}

I Škoti i Katalonci kompaktno naseljavaju teritorij na kojem čine većinsko stanovništvo. Što se tiče površine, Španjolska zauzima $506.000 \mathrm{~km}^{2}$, za razliku od Katalonije koja ima 32.000 $\mathrm{km}^{2}$ (približno 6 \% ukupnog španjolskog teritorija); u Kataloniji živi približno 7,5 milijuna ljudi od ukupno 46,5 milijuna koliko živi u Španjolskoj (u Kataloniji živi 16 \% ukupnog broja španjolskog stanovnika). ${ }^{128}$ Područje Škotske zauzima $78.400 \mathrm{~km}^{2}$, za razliku od $165.000 \mathrm{~km}^{2}$ (oko 50 \% ukupne površine) UK-a, dok u Škotskoj živi približno 5,2 milijuna ljudi u odnosu na 57,8 milijuna koji žive u ostatku UK-a (približno 10 \% ukupnog broja stanovnika UK-a živi u Škotskoj). ${ }^{129}$ To je velika razlika u stanovništvu, a bitno manja u površini škotskog teritorija. ${ }^{130}$

Oba secesionistička pokreta svoje zahtjeve iznose mirnim putem. Imaju svoje parlamente, vlade i premijere. Središnje vlasti zadržale su uobičajene ovlasti i nadležnosti u vanjskim poslovima, obrani, imigraciji, državljanstvu, energetskoj industriji, porezu i transportu. I u Španjolskoj i u UK-u postoje velike ekonomske nejednakosti i tenzije, nezadovoljstvo politikom poreza, kao i političke, socijalne i kulturne razlike među ekonomskim grupama. Kriza u eurozoni produbila je već postojeću krizu i uzburkala nacionalističke strasti u objema regijama. Secesionisti tvrde da ne samo da mogu samostalno egzistirati kao male europske države nego da bi im ekonomski bilo lakše da su neovisni. Istu retoriku slušamo u objema regijama. Kako je Španjolsku, za razliku od UK-a, snažno pogodila ekonomska kriza 2008. godine, u Kataloniji su ti navodi još jači. Također, i jedni i drugi secesionisti bezbolnim smatraju i priželjkuju ulazak njihovih regija u članstvo EU-a nakon ostvarivanja samostalnosti. Naime, ono što Katalonija dijeli sa Škotskom jest jaka eurofilija.

126 Shaw, J. op. cit. (bilješka 117), str. 154.

127 „Scottish independence: Referendum demand will be rejected“, March 16, 2017 na https://www.bbc.com/news/ukscotland-39293513/.

128 El Instituto Nacional de Estadística, Madrid, 2018 https:/www.ine.es/dyngs/INEbase/en/operacion.htm?c=Estadistica_C\&cid= 1254736176951\&menu=ultiDatos\&idp=1254735572981/ i opći podaci za Kataloniju na službenim stranicama Encyclopaedia Britannica na https://www.britannica.com/place/Spain i https://www.britannica.com/place/Catalonia/.

129 Edward, D., EU Law and the Separation of Member States, Fordham International Law Journal, Vol. 36, 2013, str. 1155.

130 Ibidem. 
Ono što je specifično za oba secesionistička slučaja, a primjećuje se i u drugim analognim secesionističkim pokretima, jest pozivanje da su njihovi zahtjevi za samostalnošću utemeljeni na volji građana ili naroda (za većom kontrolom u ustavnopravnim odlukama). ${ }^{131}$ Iako, čini se, niti je većina Katalonaca, niti većina Škota za neovisnost. Postoji očito dovoljan broj onih koji nemaju ambicija za neovisnošću, zadovoljni su trenutačnim državnim i društvenim uređenjem ili žele bitno manje intervencije u pravno-političko uređenje države i društva od onoga koje sa sobom nosi secesija. Također, dio njih ne želi plaćati (pre)visoku cijenu ni preuzimati rizike secesije.

Škotska i Katalonija imaju dugu povijest zahtjeva prema visokom stupnju autonomije i, u ovo suvremeno doba, zahtjeva za neovisnošću. Iako ni Španjolska ni UK nisu federalne države, imaju zavidnu razinu podjele moći i ovlasti između središnjih vlasti i regija. Španjolska od kraja 70-ih, a UK od formiranja škotskog Parlamenta 1998. godine. Kako je Ujedinjeno Kraljevstvo Velike Britanije i Sjeverne Irske formalno unitarna parlamentarna ustavna monarhija s vladama u Sjevernoj Irskoj, Walesu i Škotskoj, neki tvrde da bi događanja oko neovisnosti u Škotskoj mogla potaknuti UK u smjeru „federalizacije“ UK-a. ${ }^{132}$ No, ne treba zaboraviti, iako federalizam smanjuje mogućnost za secesionizam, ne može u cijelosti isključiti buduće secesionističke zahtjeve s političke agende. ${ }^{133}$

Koje su razlike između škotskih i katalonskih iskustava? Za razliku od zabrane i neočekivane represije španjolskih vlasti na dan održavanja „neformalnog“ referenduma o neovisnosti u Kataloniji, škotska Vlada i Vlada UK-a u demokratskom su i pozitivnom duhu dogovorile Zakon o referendumu o neovisnosti Škotske. ${ }^{134}$ U Španjolskoj središnje vlasti zauzimaju, za demokratske standarde, prilično rigidan stav i odbijaju pregovarati sa secesionistima. Argumente su sveli na „zabranjeno je Ustavom“. S druge strane, London je hrabro ušao u vrlo delikatne pregovore te sa samopouzdanjem dopustio Škotima referendum o neovisnosti. To bi mogao i biti razlog zbog kojeg je daleko veći broj Katalonaca za secesiju nego Škota, jer su Škoti imali mogućnost izbora i doživljeni su kao partneri u rješenju sukobljenih zahtjeva i vizija. Ključna razlika između Katalonije i Škotske kontinuiran je dijalog britanskih i škotskih vlasti, za razliku od španjolskih vlasti koje svu raspravu prekidaju argumentom „secesija je protuustavna“ $\mathrm{i}$ o tome ne smijemo i nemamo što pregovarati.

Škotski referendum o neovisnosti tako indicira važan presedan. Škotska je imala pravo odlučiti o povijesnom pitanju svoje neovisnosti: a) dobivši suglasnost matične države (UK-a) da inicira referendum, b) postaviti direktno i nedvosmisleno pitanje prema neovisnosti na refe-

131 O fenomenu ulaženja u „eru referenduma“ na subnacionalnoj razini nacionalizma detaljnije vidi Tierney, S., 'Should the People Decide?' Referendums in a Post-Sovereign Age, the Scottish and Catalonian Cases (u daljnjem tekstu: „Tierney, Should the People Decide?"), Netherlands Journal of Legal Philosophy, Vol. 45, No. 2, 2016, str. 99. i dalje.

132 Već su reforme 1998. inicirale decentralizaciju i fragmentaciju državnih struktura uspostavom parlamenata u Škotskoj, Walesu i Sjevernoj Irskoj. Ti su parlamenti dobili ovlasti zdravlja, obrazovanja, stanovanja i agrikulture, uključujući ribarstvo, zaštitu okoliša, turizam, sport, kulturna dobra i ekonomski razvoj. Blanke and Abdelrehim, op. cit. (bilješka 44), str. 536.

133 Secesionisti su na televiziji, u novinama, mogu se slobodno kandidrati na razne državne funkcije, a secesionističke stranke uredno dobivaju znatnu podršku na izborima. Kymlicka, W., Federalism and Secession: At Home and Abroad, Canadian Journal of Law \& Jurisprudence, Vol. 13, No. 2, 2000, str. 214.

134 Scottish Independence Referendum, UK Government Services and Information, na https://www.gov.uk/government/topicalevents/scottish-independence-referendum/about/. 
rendumu i c) odluku donijeti na temelju obične većine. ${ }^{135}$ I pregovori Škotske i središnjih vlasti UK-a bili su povijesni i bez presedana u EU-u, a rezultirali su suglasnošću UK-a da Škotska organizira glasanje. ${ }^{136}$ Da su Škoti glasali za secesiju, takav rasplet događanja u međunarodnom pravu bio bi smatran „konsenzualnom secesijom“, 137 za razliku od Katalonije koja ide putem unilateralne secesije, suprotno volji matične države.

I što se tiče ekonomskih prilika u Kataloniji i Škotskoj, bitne su razlike. Za razliku od Katalonije, čija ekonomija bitno odskače od drugih dijelova Španjolske, Škotska je siromašniji dio UK-a. Naime, bogate secesionističke regije vjeruju da bitno pridonose budžetu središnjih vlasti, ali da nemaju, u skladu s time, zadovoljavajuće kapitalne investicije. ${ }^{138}$ Te bogate regije jednako se tako žale na malen broj predstavnika u središnjim vlastima te nedovoljnu kontrolu nad vlastitim bogatstvima. ${ }^{139}$ Španjolska bi odcjepljenjem Katalonije izgubila 6 \% teritorija i samo 16 \% stanovništva, ali i petinu BDP-a. Jedna od ključnih kritika katalonskih secesionista i izvor sukoba sa središnjim vlastima u Madridu povezan je s čl. 157. st. 1. Ustava Španjolske kojim se, na temelju „solidarnosti među regijama Španjolske“ (čl. 2. Ustava), uspostavljaju tzv. kompenzacijski fondovi među autonomnim zajednicama. Tim se sustavom pomaže ekonomski slabijim regijama, a sredstva se pretaču iz bogatijih regija. Katalonija je, primjerice, za svaki euro plaćen kroz poreze nazad dobila samo pedeset sedam centi, što su Katalonci prikazali kao „fiskalnu pljačku“. ${ }^{140}$ No, takav koncept pomoći uobičajen je način funkcioniranja modernih socijalnih država.

Za razliku od Katalonije, koja se žali da velik dio njezinih prihoda nepovratno odlazi u Madrid (i druge dijelove Španjolske), u Škotskoj je situacija obrnuta. Znatan dio prihoda UK-a odlazi u Škotsku. Generalno, ipak je lakše pustiti ekonomski slabije regije (npr. Škotsku), jer će središnjim vlastima i većinskom narodu u ostatku matične države financijska „utjeha“ biti to što više ne moraju sufinancirati secesionistički teritorij (slično bi se, vjerujemo, dogodilo i u Francuskoj u odnosu na Korziku). ${ }^{141}$ Škoti bi se (i Korzikanci) ponadali da bi taj manjak nadoknadili ulaskom u EU. S druge strane, bit će teže pustiti bogate regije, kao što je slučaj s Katalonijom. Odlaskom Katalonije središnje španjolske vlasti izgubile bi znatan dio prihoda. ${ }^{142}$

Škotski secesionisti, zanimljivo, izbjegavaju bilo kakve paralele s Katalonijom i smatraju da imaju drukčiji politički put u odnosu na Katalonace. Primjerice, u kampanji „Yes Scotland“ izrađeni su plakati na kojima je bilo navedeno devet malih država „bogatijih“i deset manjih

\footnotetext{
135 Levites, B., The Scottish Independence Referendum and the Principles of Democratic Secession, Brooklyn Journal of International Law, Vol. 41, No. 1, 2015, str. 376.-377.

136 Ibidem, str. 393. i 395.

137 Pronto, A. N., Irredentist Secession in International Law, Fletcher Forum of World Affairs,Vol. 40, No. 2, Summer 2016 , str. 112.

138 Yakoviyk I., Okladna, M. G., Orlovskyy, R. R., Separatism in the United Europe: Old Problems with a New Face, Проблеми законності, Issue 140, 2018, str. 135.

139 Ibidem.

140 Podaci su za 2012. godinu. Gonzales, op. cit. (bilješka 54), str. 126.

141 Lloyd, T., Union and Division in Europe, International Journal, Vol. 52, No. 4, 1997, str. 553.-554.

142 Ibidem.
} 
država „sigurnijih“ od UK-a. ${ }^{143}$ Škoti se radije pozivaju na nordijske države te druge bogate europske držav(ic)e, a Katalonci, pak, na baltičke države - i Škotsku. ${ }^{144}$

\section{POSTOJI LI U MEĐUNARODNOM PRAVU ILI PRAVU EU-A PRAVO NA ODCJEPLJENJE?}

U međunarodnom pravu nema odredbi o „pravu na (unilateralno) odcjepljenje“ ni samostalno ni u okviru prava na samoodređenje. No, odcjepljenje nigdje nije ni zabranjeno. U kontekstu secesije postoje međunarodnopravne odredbe o zaštiti teritorijalnog integriteta država kao temeljnog načela međunarodnog prava. No, zaštita teritorijalnog integriteta u funkciji je zaštite od vanjske agresije, ne od entiteta unutar državnih granica. Postoje i pravila o zabrani stranih intervencija u unutarnja pitanja druge države i, naravno, pravilo o zabrani uporabe sile. Svako područje može (pokušati) proglasiti neovisnost, no hoće li ispunjavati uvjete za državnost i biti ravnopravan i prihvaćen član međunarodne zajednice, ostaje pitanje. Države mogu i ne moraju priznati novi entitet samoproglašen nakon secesije.

\subsection{SAMOOODREĐENJE I ODCJEPLJENJE U MEĐUNARODNOM PRAVU}

Samoodređenje se navodi u nizu međunarodnih dokumenata, kako onih obvezujućih tako i, u puno većem broju, neobvezujućih. ${ }^{145}$ Tako ćemo „pravo na samoodređenje“ naći u Povelji UN-a ${ }^{146}$, Rezoluciji Opće skupštine o pravu naroda i nacija na samoodređenje (1952. $)^{147}$, Deklaraciji o davanju neovisnosti kolonijalnim zemljama i narodima (1960.) ${ }^{148}$, Međunarodnom paktu o građanskim i političkim pravima (1966. ${ }^{149}$, Međunarodnom paktu o ekonomskim, socijalnim i kulturnim pravima (1966.) ${ }^{150}$, Deklaraciji Opće skupštine UN-a o načelima me-

143 Države koje su se nalazile na oba popisa bile su: Island, Švedska, Finska, Irska, Norveška, Danska, Luksemburg, Švicarska i Austrija. Bourne, Angela K, Europeanization and Secession: The Cases of Catalonia and Scotland, Journal on Ethnopolitics and Minority Issues in Europe, Vol 13, No 3, 2014, str. 111.-112.

144 Ibidem, str. 113.

145 O izvorima međunarodnog prava vezanim uz pravo na samoodređenje vidi detaljnije Cassese, op. cit. (bilješka 2), Crawford, op. cit. (bilješka 3), Musgrave, Thomas D, Self-Determination and National Minorities, Oxford Clarendon, 1997. Itd. Konačno, kako bi što jasnije razumjeli prirodu pravo na samoodređenje, također su nam u ovom kontekstu značajni i različiti izvještaji organa Ujedinjenih naroda, kako kroz povijest, tako do danas. Vidi, primjerice, The Right to Self-determination Implementation of United Nations Resolutions, Study prepared by Hector Gros Espiell, Special Rapporteur of the Sub-Commission on Prevention of Discrimination and Protection of Minorities, United Nations, 1980.; The Right to Self-determination: Historical and Current Development on the Basis of United Nations Instruments, Study prepared by Aureliu Cristescu, Special Rapporteur of the SubCommission on prevention of Discrimination and Protection of Minorities, United Nations, 1981.; Boutros Ghali, B., An Agenda for Peace: Preventative Diplomacy, Peacemaking and Peace-keeping, Report of the Secretary-General pursuant to the Statement adopted by the Summit Meeting of the Security Council on 31 January 1992, A/47/277. Itd.

146 Povelja Ujedinjenih naroda, Narodne novine - Međunarodni ugovori 15./1993.

147 A/RES/637 (VII) of 20 December 1952.

148 A/RES/1514 (XV) of 14 December 1960.

149 United Nations, Treaty Series, vol. 999, p. 171.

150 United Nations, Treaty Series, vol. 993, p. 3. 
đunarodnog prava o prijateljskim odnosima i suradnji među državama u skladu s Poveljom UN-a (1970.) ${ }^{151}$, Deklaraciji UN-a o pravima domorodačkih naroda (2007.) ${ }^{152}$, Bečkoj deklaraciji i Programu akcije Svjetske konferencije o ljudskim pravima (1993.) ${ }^{153}$ itd. Samoodređenje (i problematiku odcjepljenja) pronaći ćemo i u odlukama nacionalnih i međunarodnih sudova. I ti će nam tekstovi biti dragocjeni kako bismo razumjeli prirodu prava na samoodređenje. U tome kontekstu navest ćemo dva najvažnija. Najčešće rabljen tekst povezan sa samoodređenjem naroda odluka je Vrhovnog suda Kanade o secesiji Quebeca (1997.) ${ }^{154} \mathrm{U}$ tom se tekstu Vrhovni sud Kanade upustio u vrlo detaljno analiziranje odredbi međunarodnog i unutrašnjeg prava Kanade povezanog sa samoodređenjem i zahtjevima za odcjepljenjem Quebeca te dao odgovore na pitanja je li zahtjev Quebeca za odcjepljenjem u skladu s međunarodnim pravom i/ili unutrašnjim pravom Kanade i jesu li ta dva pravna sustava u mogućem sukobu oko tog pitanja. Vrhovni je sud utvrdio da Quebec nema pravo na odcjepljenje ni po međunarodnom ni po unutrašnjem pravu Kanade. Drugi važan sudski dokument u ovom kontekstu je Savjetodavno jest mišljenje Međunarodnog suda o jednostranom proglašenju neovisnosti Kosova. U tom Mišljenju Sud je utvrdio kako jednostrano proglašenje neovisnosti nije u suprotnosti s međunarodnim pravom jer u međunarodnom pravu nema zabrane objave takve deklaracije. ${ }^{155}$ Ako je i bilo slučajeva u kojima su takve deklaracije proglašene protupravnim, radilo se o slučajevima kada je protupravno upotrijebljena sila.

U međunarodnom pravu sporno je pitanje koje skupine imaju pravo na samoodređenje i što samoodređenje u njihovom slučaju uključuje. ${ }^{156}$ Nejasno je i u kojem trenutku one stječu pravo na samoodređenje i na koji ga način mogu ostvariti. Ono što je jasno jest da pojedinci nemaju pravo na samoodređenje jer to nije individualno već kolektivno ljudsko pravo. U razdoblju od osnivanja Ujedinjenih naroda pa do završetka Hladnog rata iskristalizirale su se, navodi Cassese, tri skupine naroda koje imaju pravo na samoodređenje. To su a) ovisni narodi, b) narodi pod rasističkim režimima i c) narodi pod stranom vojnom okupacijom ili aneksijom. ${ }^{157} \mathrm{U}$ tim je slučajevima više-manje moguće jasno utvrditi tko su narodi (koji imaju pravo na samoodređenje) i u kojem postupku (na koji način) to pravo mogu ostvariti. ${ }^{158}$ Katalonija i Škotska, jasno, ne pripadaju nijednoj među tim skupinama naroda.

Međunarodno pravo secesiju nije definiralo kao ilegalnu aktivnost, prije je „tiho po pitanju secesije“, a secesionističke pokrete i zahtjeve stavlja više pod unutrašnje pravo države. ${ }^{159} \mathrm{Bu}$ -

$151 \mathrm{~A} / \mathrm{RES} / 2625$ (XXV) of 24 October 1970.

$152 \mathrm{~A} / \mathrm{RES} / 61 / 295$ of 13 September 2007.

153 Vienna Declaration and Programme of Action, World Conference on Human Rights, 14-25 June 1993, Vienna, Austria, A/CONF. 157/23 of 12 July 1993.

154 Reference re Secession of Quebec, Supreme Court Judgments, Canada, 1998-08-20, case no. 25506, 2 S.C.R. 217.

155 Accordance with International Law of the Unilateral Declaration of Independence in Respect of Kosovo, Advisory Opinion, 2010, ICJ Reports, p. 403.

156 O problematici definiranja pojmova naroda vidi detaljnije Vukas, B., States, Peoples and Minorities, RCADI, 1991, VI, Tome 231 de la collection, Martinus Nijhoff Publishers, The Hague/Boston/London, (1999.).

157 Vidi detaljnije Cassese, op. cit. (bilješka 2), str. 59, 130.-131, str. 141.-158. i 328.-330.

158 Ibidem.

159 Vidi Buchanan, A., Justice, Legitimacy, and Self-Determination: Moral Foundations For International Law Oxford Political Theory, Oxford, 2007, str. 331.-400.; Borgen, C. J., The Language of Law and the Practice of Politics: Great Powers and the Rhetoric of SelfDetermination in the Cases of Kosovo and South Ossetia (u daljnjem tekstu: „Borgen: The Language of Law and the Practice of Politics"), Chicago Journal of International Law, Vol. 10, No. 1, 2009, str. 8. 
dući da u međunarodnom pravu ne postoji obveza kako se mora postupiti u tom slučaju, stavi postupanje po secesionističkim zahtjevima izvlače se iz državne prakse, koja nije uniformna i ovisi o političkim i pravnim elementima. ${ }^{160} \mathrm{~S}$ druge strane, nacionalna zakonodavstva i propisi, posebno ustavni sustav, u pravilu ili ignoriraju ili su izrazito neprijateljski nastrojeni prema ideji odcjepljenja dijela teritorija. ${ }^{161}$ Španjolska je tu, kako smo vidjeli u njezinu ustavnom pravu, tipičan primjer potonjeg. S tim da, treba navesti, kršenje ustavnog prava Španjolske ne povlači za sobom i kršenje međunarodnog prava u slučaju unilateralnog odcjepljenja Katalonije.

Iako bi se moglo činiti da je međunarodno pravo neutralno prema odcjepljenju, jer ga nigdje izričito ne zabranjuje, u praksi je secesija, kako smo napomenuli, među državama izrazito omražena. I to unatoč „umjetnom priznanju prava na samoodređenje“ u UN-ovim dokumentima. ${ }^{162}$ Secesija potkopava dva stupa westfalskog sustava država-nacija: suverenost i teritorijalni integritet. ${ }^{163}$ No, s druge strane, gledajući promjene međunarodnih granica od 1945. do danas, one su velike. Ujedinjeni narodi prilikom osnivanja imali su pedeset jednu državu-članicu, a danas ih imaju sto devedeset tri. Najčešće se radilo o okončanim procesima dekolonizacije i raspadima države, a manje o nastancima država secesijom i ujedinjenjem. Iako su države i međunarodne organizacije zagovornici statusa quo po pitanju postojećih međunarodnih granica, promjene državnih granica i nastanci novih država su prirodna pojava. Pogotovo je teško i izazovno održati na duže vrijeme umjetne multinacionalne države. No, obeshrabrujuće za svaki secesionistički pokret jest činjenica da su nastanci država secesijom od matične države, ipak, rjeđi. Od Drugog svjetskog rata do danas uspješno se, de facto i de iure, odcijepio mali broj država. Iako teoretičari nisu uvijek suglasni pri navođenju primjera za uspješnu secesiju, uobičajeno se navode odcjepljenja Singapura od Malezije 1965., Bangladeša od Pakistana 1971., Baltičkih republika (Litva, Latvija i Estonija) od SSSR-a 1991., ${ }^{164}$ Eritreje od Etiopije 1993., Istočnog Timora od Indonezije 1999., Crne Gore od Srbije 2006., Kosova od Srbije 2008. i Južnog Sudana od Sudana 2011. ${ }^{165}$ Neki autori navode da u svijetu ima sedamdesetak secesionističkih pokreta, od kojih je dvadesetak aktivno. ${ }^{166}$

Općenito, što se tiče davanja "prava na odcjepljenje", teoretičari se mogu podijeliti u tri skupine. Jedna skupina teoretičara zagovara status quo i poziva se na poštovanje načela teritorijalnog integriteta države kao temeljnog načela međunarodnog prava; druga skupina daje

160 Edward, op. cit. (bilješka 129), str. 1161.

161 Perry and Rehman, op. cit. (bilješka 122), str. 30.

162 Connolly, op. cit. (bilješka 12), str. 67-68. Vidi i: Patrick, T. Y., The Zeitgeist of Secession amidstthe March towards Unification: Scotland, Catalonia, and the Future of the European Union, Boston College International and Comparative Law Review, Vol. 39, No. 1, 2016, str. 205.

163 Connolly, op. cit. (bilješka 12), str. 67.

164 Baltičke su države okupirane i aneksirane od strane SSSR-a 1940. korištenjem sile, a svoju su neovisnost proglasile 1990. Već 6. rujna 1991. Državno vijeće SSSR-a jednoglasno je priznalo neovisnost Baltičkih država, a dana 12. rujna 1991. Vijeće sigurnosti predložilo je njihovo primanje u UN. Crawford, op. cit. (bilješka 3), str. 393-394. Cassese, također, smatra da su Baltičke republike „stekle pravo na secesiju“ od SSSR-a, za razliku od svih drugih republika bivšeg SSSR-a koje to pravo nisu imale, upravo jer su Baltičke republike bile okupirane i anektirane od strane druge vojne sile. Te su tri države na invalidnosti tajnih sporazuma SSSR-a i nacističke Njemačke 1939. te protupravne inkorporacije njihovih tada neovisnih država u SSSR 1940 . I tu je međunarodno pravo puno jasnije po pitanju ostvarenja prava na samoodređenje „naroda pod stranom okupacijom“. Cassese, op. cit. (bilješka 2), 260.-263.

165 Vidi, primjerice, Coggins, B. L., The History of Secession: An Overview, u: Pavkovic, A., Radan, P., (eds.) The Ashgate Research Companion to Secession, , Routledge, 2011, str. 23. i dalje.Također, Crawford, op. cit. (bilješka 3), str. 374.-448.

166 Beary, B., Separatist Movements: Should Nations Have a Right to Self-Determination?, 2 CQ Global Researcher, 2008, str. 87., cit. prema Perry and Rehman, op. cit. (bilješka 122), str. 66. 
mogućnost odcjepljenja ako se dotičnoj skupini teško krše ljudska prava bez mogućnosti budućeg suživota sukobljenih strana (tzv. remedijalna teorija odcjepljenja); dok treća skupina autora, kojih je najmanje, zagovara da svi narodi imaju pravo na samoodređenje do odcjepljenja bez posebnih uvjeta. ${ }^{167}$ Samoodređenje, uključujući odcjepljenje, iznimno se počelo tolerirati suprotno volji središnjih vlasti država u slučaju kada su sukobi između središnjih vlasti i secesionista dosegnuli razmjere velikih humanitarnih katastrofa i teških sustavnih kršenja ljudskih prava, primjerice na Kosovu. U tom slučaju, kako je Buchanan ranije definirao u svojoj teoriji remedijalne secesije, secesija će se dopustiti samo kao zadnje sredstvo kada su skupini na određenom teritoriju unutar postojeće države uskraćena temeljna ljudska prava i slobode i ugrožen opstanak. ${ }^{168}$ Povezano s time, sporan je trenutak kada se neka „manjina“ odjednom počinje proglašavati i smatrati „narodom“ (koji ima pravo sa samoodređenje). Manjine nisu ipso facto narodi, ali u iznimnim slučajevima imaju, kako to Buchheit zove, „pravo reverzije“ $\mathrm{i}$ tako tvore „potencijalne narode“. ${ }^{169}$ Primjerice, Albanci na Kosovu bili su jasna manjina u Srbiji i žrtva sustavne i višedesetljetne opresije te teških kršenja ljudskih prava koji su kulminirali devedesetih godina. U to vrijeme počeli su se deklarirati kao „Kosovari“ te raditi određene razlike u odnosu na Albance u Albaniji. Također, svima je bilo jasno da je suživot sa srpskom većinom nemoguć. Činjenica da su nastanjivali kompaktan teritorij koji su dominantno naseljavali, također im je osobito išla u prilog. Tako je albanska manjina na Kosovu postala narod koji na temelju remedijalne secesije ima pravo na samoodređenje odcjepljenjem. Time manjine danas postaju „rivali za samoodređenje”, „stalna prijetnja narodima”170.

Konačno, treba napomenuti da bi neka buduća neovisna Škotska ili Katalonija morale zatražiti članstvo u Ujedinjenim narodima u skladu s čl. 4. Povelje Ujedinjenih naroda, dok bi, zasigurno, Velika Britanija, odnosno Španjolska, opstale kao neovisne države (i države-sljednice) i tako nastavile biti članice UN-a. ${ }^{171}$ Isto bi se odnosilo na sve druge međunarodne organizacije i tijela. U međunarodnom je pravu općeprihvaćeno pravilo da novoformirana država koja se odcijepila započinje svoj život bez obveza poštovanja ugovora koje je zaključila matična država od koje se upravo odcijepila (uz izuzetak ugovora koji se tiču granica) i to je vidljivo iz kontinuirane prakse država. ${ }^{172}$ Ta nova država, kako Shaw kaže, „započinje svoj međunarodni život slobodna od ugovornih prava i obveza koje su se primjenjivale na njenog bivšeg suverena“, a razlog tomu je stav da je teško održati pravilo da su države vezane posebnih ugovorima koje - nisu potpisale. ${ }^{173}$

167 Ibidem, str. 492.

168 Buchanan, A., Democracy and Secession, u: Moore, M., (ed.) National Self-Determination and Secession, Oxford University Press, Oxford New York, 1998, str. 25. i dalje.

169 Pravo reverzije javlja se, stoga, u slučajevima kada je nekom dijelu stanovništva "uskraćeno pravo na unutarnje samoodređenje". Buchheit, L. C., Secession, New Haven: Yale University Press, 1978, str. 72., navedeno prema Musgrave, T. D., Self-Determination and National Minorities, Oxford Clarendon, 1997, str. 171., bilješka 113.

170 Vukas, op. cit. (bilješka 156), str. 322.-323. i Thornberry, P., The principle of self-determination, u: Warbrick C., Lowe, V., (eds.) The United Nations and the Principles of International Law, Essays in memory of Michael Akehurst, Routledge, London, 1996, str. 187

171 Slično se dogodilo sa stvaranjem Pakistana, kada su Indiju Britanci, ali i UN, smatrali sukcesorom 1947. Poslije će se isti pristup primijeniti kod odcjepljenja Bangladeša od Pakistana 1971., Crne Gore od Srbije (2006.) i Južnog Sudana od Sudana (2011.). I druge države, npr. Češka, Slovačka i Eritreja, trebale su aplicirati za članstvo, kao i države nastale na području bivše Jugoslavije. Tierney, Legal Issues Surrounding the Referendum on Indepedence for Scotland, op. cit. (bilješka 107), str. 380.-381.

172 Shaw, M. N., International law, Cambridge University Press, 6th ed, 2008, str. 974.-977. 


\subsection{PROBLEMATIKA ODCJEPLJENJA OD DRŽAVA-ČLANICA EU-A}

Međunarodno pravo dio je prava EU-a i kao takvo veže institucije i države-članice EU-a. ${ }^{174}$ Pravo na samoodređenje nije priznato ni u okviru EU-a ni Vijeća Europa. Naći ćemo ga tek kao referencu u Helsinškom završnom aktu (1975.) i Pariškoj povelji za novu Europu (1990.), a to su dokumenti koji pravno ne obvezuju. ${ }^{175}$ Kao ni u međunarodnom pravu, niti jedna odredba nekog EU-ova ugovora ne zabranjuje odcjepljenje. Članstvo u EU-u, također, ne osigurava „dodatnu zaštitu“ državama-članicama da očuvaju svoj nacionalni identitet ili teritorijalni integritet. ${ }^{176}$ Dok pri UN-u postoji praksa primanja novih država nastalih odcjepljenjem, nema presedana vezanih uz članstvo u EU-u u slučaju odcjepljenja dijela teritorija neke države-članice. ${ }^{177}$ Takav se slučaj još nije dogodio u praksi EU-a. Škotska i Katalonija najdalje su otišle u tom procesu.

Zanimljivo da su i katalonski i škotski secesionisti zauzimali stav da bi, u slučaju proglašenja neovisnosti i nastanka novih država, imali pravo automatizmom ući u EU. Ili barem brzinskom procedurom, po nekim povlaštenim i olakšanim uvjetima, u odnosu na standardno propisane uvjete i postupke. Naime, i Katalonija i Škotska smatraju da EU treba zauzeti nekakav „fleksibilan stav“ o njihovu budućem članstvu u EU-u, s obzirom na to da su i Katalonci i Škoti, članstvom Španjolske i UK-a u EU-u, dugo prisutni i aktivni u postojećoj mreži europskih institucija. ${ }^{178}$ To pitanje izazvalo je velike rasprave, iako je odgovor na njega već utvrđen i jasan. Tvrditi da bi se radilo o „dvostrukom primanju“ u EU kada bi se, primjerice, od neovisne Katalonije i Škotske tražilo da zatraže regularno primanje u članstvo, čini se i pravno i politički neodrživim. ${ }^{179}$ Dovelo bi do toga da bi svaka neovisna država nastala secesijom (npr. Sicilija, Korzika, nekoliko balearskih, grčkih ili švedskih otoka) na području EU-a u startu ispunjavala sve političke, ekonomske, pravne i administrativne uvjete. ${ }^{180}$

I tadašnji predsjednik Europske komisije José Manuel Barroso, u pismu britanskom Parlamentu u prosincu 2012. godine, izjavio je, vrlo brzo nakon što su teze o „brzinskom ulazu u EU“ izašle u javnost, kako se EU temelji na Ugovorima koji se odnose samo na države-članice koje su ih ratificirale. ${ }^{181}$ Ako dio teritorija države-članice secesijom prestane biti dio te države i nastane nova država, jednostavno, Ugovori EU-a više se neće primjenjivati na taj teritorij. ${ }^{182}$

174 Levrat, N., The Right to National Self-determination within the EU: a Legal Investigation, ECPR General Conference Universitetet i Oslo, Oslo, September 6-9, 2017, https://ecpr.eu/Events/PaperDetails.aspx?PaperID=37223\&EventID=96/, str. 1.

175 Ibidem, str. 4.

176 Ibidem, str. 7. i 8.-9.

177 Tierney, Legal issues Surrounding the Referendum on Indepedence for Scotland, op. cit. (bilješka 107), str. 382.

178 Generalitat, Memorandum \#2, Data and Question Announced for Catalonia Self-determination Vote, Barcelona, December 13, 2013, cit. prema Bourne, op. cit. (bilješka 143), str. 106.

179 Piris, J.-C., Political and Legal Aspects of recent Regional Secessionist Trends in some EU Member States (I), u: Closa, C., (ed.) Secession from a Member State and Withdrawal from the European Union, Troubled Membership, Cambridge University Press, 2017, str. 82.-83. i dalje.

180 Ibidem.

181 For the full text of Barroso's letter to the House of Lords, see Letter from Jose Manuel Barroso, President, European Comm'n, to Lord Tugendhat, Acting Chairman, U.K. House of Lords Economic Affairs Committee (October 10, 2012), http://www. parliament.uk/documents/lords-committees/economic-affairs/ScottishIndependence/EA68.

182 Jose Manuel Barroso, President of the European Commission, Brussels, Barrosos (December 10, 2012), to Lord Tugendhat, na https://www.parliament.uk/documents/lords-committees/economic-affairs/ScottishIndependence/EA68_Scotland_and_the_ EU_Barroso's_reply_to_Lord_Tugendhat_101212.pdf/. 
„Ako neka zemlja stekne nezavisnost, radi se o sasvim novoj državi koja mora ispočetka pregovarati s Europskom unijom“, izjavio je tom prilikom Barroso. No, nema presumpcije da bi neka buduća neovisna Katalonija i Škotska apriori ispunjavala sve uvjete, kriterije i standarde koje traži EU. Službeno, prema Eurostatu, samo u Europskoj uniji postoji devedeset osam regija. ${ }^{183}$ Teško će zamisliti da će sve one zatražiti i dobiti neovisnost. Trenutačno, prema Coppietersu, u Europi ima između dvadeset i dvadeset pet „značajnih“ separatističkih pokreta. ${ }^{184}$ No, niti jedan od njih, za sada, nije došao do razine koju imaju katalonski i škotski secesionisti.

Prije nekoliko godina sveučilišni profesor prava Weiler u uvodniku EJIL-a objavio je tekst koji je izazvao burnu raspravu na temu odcjepljenja u liberalno-demokratskim europskim državama. ${ }^{185}$ I sam Weiler poslije je priznao da nijedan njegov tekst nije nikada izazvao takav "gnjev“" određenog dijela čitatelja kao njegov članak o katalonskom secesionizmu. ${ }^{186} \mathrm{~S}$ druge strane, njegove su stavove predvidljivo podržali oni koji se protive secesionističkim pokretima i zahtjevima. U tom tekstu Weiler je, naime, naglasio „ogromnu empatiju i simpatiju“ prema Kataloncima koji žele imati zaseban kulturni i politički identitet, ali im i predbacio da je „karta Franca“ kao opravdanje za secesiju zapravo „smokvin list“ za socijalni i ekonomski egoizam, kulturnu i nacionalnu oholost te "gole ambicije“ lokalnih političara. ${ }^{187}$ Weiler je katalonskom narodu, dakle, cinično „priznao“ pravo na samoodređenje, ali im je istodobno to pravo uskratio. Katalonski secesionisti ostatak Španjolske vide kao „strane osvajače“ i jasno formuliraju stav da ne više žele biti žrtve nametanja nekakvoga višeg i dominantnijeg „španjolskog nacionalnog identiteta“. Pogotovo su svježa sjećanja iz brutalnoga Francovog perioda koja se naprosto ne mogu prevladati ni ignorirati. No, Weiler im ustvari uskraćuje pravo da (i dalje) budu ogorčeni na represivni period Francove vlasti, a upravo su ta sjećanja visoko na listi razloga za odcjepljenje. Proces pomirbe Katalonaca sa Španjolcima očito je, za dio Katalonaca, neuspješan. Ni Quebec ni Škotska nemaju takvu razinu ogorčenosti prema središnjim vlastima niti su bili žrtve takve opresije kao Katalonci kroz povijest.

Pri traženju odcjepljenja secesionisti izdaju, smatra Weiler, ideale solidarnosti i ljudske integracije koji čine temelje Europe. ${ }^{188}$ Weiler je zato stava da to „diskvalificira moralno i politički Kataloniju i slične od budućeg članstva u EU-u“. ${ }^{189}$ Argumentira to stavom da su propustili

183 Najveće su regije Manner-Suomi (Finska) i Norra Sverige (Švedska), a najmanje Regija Brisel i Malta. Najbrojnije su NordrheinWestfalen (Njemačka) sa 17,5 milijuna stanovnika i Nord-Oves (Italija) sa 16 milijuna stanovnika. Najmanje po broju stanovnika jesu Åland (Finska) sa 28,500 i Região Autónoma dos Açores (Portugal) s 247.000 stanovnika. Eurostat Manuals and guidelines: Regions in the European union, Nomenclature of Territorial Units for Statistics, NUTS 2013, EU-28, European Union, 2015 , str. 7. i 8.

184 Coppieters, B., Secessionist Conflicts in Europe, in: Doyle, D.H, (ed.) Secession as an International Phenomenon. From America's Civil War to Contemporary Separatist Movements, Athens, GA, London: University of Georgia Press, 2010, str. 237. i 247, cit. prema Connolly, op. cit. (bilješka 12), str. 79.

185 Weiler, J. H. H., Catalonian Independence and the European Union, European Journal of International Law, Editorials, Vol. 23/4.

186 Weiler, J. H. H., Scotland and the EU: a comment, UK Constitutional Law Association, https://ukconstitutionallaw.org/2014/09/10/ debate-j-h-h-weiler-scotland-and-the-eu-a-comment/.

187 Weiler, J. H. H., Secessionism and Its Disconents, u: Closa, C., (ed.) Secession from a member state and Withdrawal from the European Union - Troubled Membership, Cambridge Universtiy Press, 2017, str. 17.

188 Ibidem, str. 19. Vidi, također, Weiler, Joseph H. H, Slouching towards the Cool War; Catalonian Independence and the European Union (u daljnjem tekstu: „Weiler, Slouching towards the Cool War"); Roll of Honour; In this issue A Personal Statement, European Journal of International Law, Vol. 23, No 4, 2012, str. 909.-913.

189 „Pomama“ za secesijom u Europi temelji se na premisi da će te neke nove buduće države naći „sigurno utočište“ u EU-u kao nove države-članice. Uskratom te pretpostavke, „apetit za neovisnošću bi se značajno umanjio“, a grubo „idemo sami“ zvučalo bi prijeteći. Ibidem, str. 910.-911. 
postići dogovor da svoje političke, socijalne, kulturne i ekonomske razlike prethodno riješe s madridskim vlastima. ${ }^{190}$ Predbacivati Kataloncima da nisu pregovarali i dogovarali svoju budućnost sa središnjim španjolskim vlastima suvišno je, s obzirom da su upravo te središnje vlasti ignorirale sve pokušaje dogovora sa secesionistima „jer su takve teme protuustavne“. Katalonija „izdaje ideale solidarnosti i ljudske integracije na kojima Europa počiva“, tvrdi Weiler. ${ }^{191}$ No katalonski nacionalizam nije nekakav arhaični nacionalizam iz 19. st., kako to s podcjenjivanjem gleda, već prilično sofisticiran i visoko razvijen oblik nacionalnog identiteta. Fascinantno je da su se sva ta stoljeća, a pogotovo u 20. st. kada su bili na najvećem udaru, Katalonci uspjeli očuvati svoj grupni identitet i nisu asimilirani u španjolsko/kastiljansko društvo unatoč višedesetljetnoj sustavnoj politici zatiranja katalonskog identiteta od strane središnjih španjolskih vlasti. Također je suvišno predbacivati im nacionalističke strasti, kada je cijela Europa podijeljena duž nacionalnih linija. Uostalom, i Ujedinjeno je Kraljevstvo tada „izdalo europske ideale solidarnosti i integracije“ kada je dopustilo škotskim secesionistima referendum o neovisnosti. Weiler se protivi nastanku novih država (odcjepljenjem) na području Europe i proširivanju kruga novih država na tlu Europe, ali istodobno nema zamjerki pri primanju novih država u EU i kontinuiranom proširivanju članstva Unije.

Samoodređenje je očito tema koja će uvijek duboko podijeliti promatrače i sudionike tih procesa. I to na one koji samoodređenje vide kao prijetnju i subverziju koja razara države, naspram onih koji ga vide kao radikalno, ali i progresivno pravo. ${ }^{192}$ Ta ambivalentnost samoodređenja može objasniti poteškoće međunarodne zajednice u artikuliranju i postavljanju pravnih standarda oko ostvarenja tog prava te rješavanje ograničenja i opasnosti koje samoodređenje nosi. ${ }^{193}$

\subsection{JESU LI KATALONCI NAROD KOJI IMA PRAVO NA SAMOODREĐENJE?}

Ne postoji univerzalno prihvaćena definicija naroda. Obično se narod opisuje na temelju određenih zajedničkih karakteristika, primjerice zajedničke povijesti, jezika, vjere, kulture, ekonomskog života i/ili teritorijalne povezanosti. Katalonci nesumnjivo jesu „narod“ na području koje dominantno naseljavaju. Uostalom, odvojen i različit kolektivni identitet priznaje im i španjolski Ustav („nacionalnost“). I Katalonija i Škotska ulaze pod definiciju „nacija bez država“, kako je to definirala Guibernau. ${ }^{194}$ Radi se o „nacijama koje, unatoč tome što imaju svoje teritorije uključene u granice jedne ili više država (..) održavaju odvojen osjećaj nacionalnog identiteta generalno utemeljen u zajedničku kulturu, povijest, vezanost uz određeni teritorij i eksplicitnu želju da vladaju sami sobom“. ${ }^{195}$ Prosecesionisti se ne identificiraju s državom

\footnotetext{
190 Ibidem, str. 911.

191 Weiler također naglašava da je takvo rezoniranje o „nacionalnom čistunstvu“ mentalitet početka 20. st. i Prvog svjetskog rata, kada se činilo da je nemoguća ideja da jedna država čini više nacionalnosti, što će i rezultirati raspadima velikih europskih carstava toga doba. Sve je to dijametralno suprotno budućem „ethosu europske integracije“. Ibidem, str. 910. i 912.

192 Cassese, op. cit. (bilješka 2), str. 5.

193 Ibidem.

194 Vidi Guibernau, M., Nations Without States: Political Communities in the Global Age, Michigan Journal of International Law, Vol. 25, No. 4, 2004, str. 1251. i 1254.

195 Ibidem.
} 
ili državama na čijem državnom teritoriju žive, nemaju ni bipolarne identitete, već središnju vlast doživljavaju kao stranu te razvijaju odvojeni osjećaj nacionalnog ideniteta. ${ }^{196}$ Katalonci imaju visoko razvijenu demokratsku svijest, snažno razvijenu lokalnu samoupravu, ekonomski su jaki i, čini se, samodostatni. Argument da su Katalonci brojčano mali narod također ne stoji jer postoji čitav niz država EU-a koje imaju manje stanovnika od Katalonije.

Općenito, Španjolska je u sličnoj pravno-političkoj situaciji kao nekoć SFRJ ili SSSR. Jedna umjetna multietnička zajednica naroda, podijeljena na pokrajine/regije od kojih su neke (posebno, primjerice, Baskija i Katalonija) bile žrtve teške represije (Francovog) režima na vlasti. S tim da su, za razliku od Kosova, u bitno boljem ekonomskom položaju. Njihova početna pozicija bitno je, dakle, povoljnija nego što je to bio slučaj ne samo u usporedbi s drugim slučajevima odcjepljenja, nego općenito ostvarenih vanjskih samoodređenja raspadima država ili okončanim dekolonizacijama. Iako u međunarodnom pravu države jasno zagovaraju nepromjenjivost postojećih granica, velik broj novoformiranih država od 1945., a posebno od 1990. do danas i dvadesetak novonastalih država izvan kolonijalnog konteksta samo u periodu nakon završetka Hladnog rata, govori nam suprotno. Raspali su se SFRJ, SSSR i Čehoslovačka, a već smo navodili primjere uspješnih odcjepljenja.

Iako se secesionisti, logično, zalažu za široko tumačenje prava na samoodređenje koje uključuje odcjepljenje, države i međunarodne organizacije kontinuirano se pozivaju na to da da je međunarodno pravo, u prvom redu, set pravila koje donose države i koje je namijenjeno državama. A države, očekivano, teško pristaju donijeti prava koja bi mogla izazvati njihova komadanja ili raspad. ${ }^{197}$ Kako u slučaju Katalonije nema mjesta za primjenu „remedijalne teorije secesije“, jer je Španjolska od kraja 70-ih demokratska država, Connolly predlaže tzv. „pregovaračku secesiju“ ${ }^{198}$ Upravo je u tom smjeru išla Velika Britanija, koja je pokazala visok stupanj spremnosti na pregovore sa škotskim nacionalistima oko referenduma o neovisnosti Škotske. ${ }^{199}$ I to treba pozdraviti. I sam Crawford, pišući pravno mišljenje na zahtjev UK-a i secesiju Škotske ${ }^{200}$, zaključuje da bi jedini pravni temelj za separaciju Škotske, kao nekolonijalnog područja, bila „suglasnost UK-a“. ${ }^{201}$ U slučaju da je do odcjepljenja Škotske došlo, to bismo odcjepljenje okarakterizirali kao „sporazumno“ i bilateralno, a ne unilateralno odcjepljenje. ${ }^{202}$ Samoodređenje naroda predstavlja, kako Brilmayer navodi, liberalne demokratske vrijednosti (s odcjepljenjem kao liberalno-demokratskom alternativom), dok bi zaštita načela teritorijal-

196 Ibidem, str. 1254.

197 Hannum, op. cit. (bilješka 7), str. 46.

198 Connolly, op. cit. (bilješka 12), str. 76.

199 Ibidem.

200 Jednu od najcitiranijih pravnih intervencija u debatu oko vanjskog identiteta neovisne Škotske Vladi UK-a dali su upravo James Crawford i Alan Boyle. Armstrong, K., An Independent Scotland in the European Union, Cambridge Journal of International and Comparative Law, Vol. 3, No. 1, 2014, str. 182.

201 Crawford, J., Boyle, A., Opinion: Referendum on the Independence of Scotland-International Law Aspects, Annex A to Scotland Office et al, Scotland Analysis: Devolution And The Implications Of Scottish Independence, Presented to Parliament by the Secretary of State for Scotland by Command of Her Majesty, HM Government, February 2013, para. 8, str. 67.

202 Ibidem. Analogan pristup mogao bi se primijeniti i na Kataloniju. Kymlicka, također, nalazi da je odcjepljenje prihvatljivo kada je dobrovoljno i suglasno jer, smatra, da odcjepljenje „nije uvijek moguće i poželjno” budući da neke novonastale države neće biti sposobne za život. Kymlicka, W.: Multicultural citizenship - a liberal theory of minority rights, Clarendon Press, Oxford, 1996, str. 186. 
nog integriteta i zadržavanje teritorijalnog status quo bilo „feudalno, nedemokratsko i opresivno“. ${ }^{203}$ Samoodređenje čuva narode, a zaštita teritorijalnog integriteta - države.

Od završetka Hladnog rata do danas postoji desetak primjera organiziranih referenduma o neovisnosti kao općeprihvaćenih mehanizama za odlučivanje o budućnosti područja i naroda koji ga nastanjuje. Dovoljno je samo navesti podatak da je sedam današnjih država-članica EU-a koje su do 1991. bile u sastavu druge veće države referendumom odlučilo o svojoj državnosti: Češka, Estonija, Hrvatska, Latvija, Litva, Slovačka i Slovenija. Stoga je referendum građana Katalonije o budućnosti Katalonije ključan u tome kontekstu i dao bi nam odgovore na niz pitanja. Tek od toga referenduma, na kojem bi se postavilo jasno pitanje o pravnoj i političkoj budućnosti Katalonije, možemo dalje procjenjivati na koje aspekte prava na samoodređenje katalonski narod ima pravo. Ili bismo dobili informaciju da je većina građana Katalonije za status quo i ostanak unutar Španjolske. No ako se pokaže da više od polovice glasača želi neovisnost Katalonije, a Španjolska im uskrati pravo na izbor i samoodređenje te ignorira zahtjeve za promjenama, o Španjolskoj više ne možemo razgovarati kao o modernoj europskoj državi. Naime, nisu svi Katalonci za neovisnost niti je Katalonija etnički homogena. Nastanjuju je i pripadnici drugih naroda i manjine. Možda secesionistički raspoloženih glasača nema dovoljno, pa rezultati takvog referenduma podupru stavove Madrida i osnaže poziciju španjolskih vlasti.

Još uvijek nije poznat precizan broj Katalonaca koji žele odcjepljenje. Mi o tom broju možemo samo nagađati i zaključivati ga na posredan način. Primjerice, po broju zastupnika secesionističkih stranaka u katalonskom Parlamentu ili na temelju rezultata anketa i popisa stanovništva iz kojih se vidi s kojim se identitetom Katalonci identificiraju. Primjerice, prema neformalnim istraživanjima 2017. godine, 36,4 \% katalonskih ispitanika deklariralo je svoj identitet kao „jednako španjolski i katalonski“, 15,9 \% kao „isključivo katalonski“, 19,8 \% kao „više katalonski nego španjolski“, 7,2 \% kao „više španjolski nego katalonski“, a 6,7\% kao „samo španjolski“ (ostali se nisu deklarirali). ${ }^{204}$ Premda se dio Katalonaca vidi unutar samostalne i neovisne Katalonije, katalonski unionisti zadovoljni su unutar Španjolske i eventualno priželjkuju jačanje regionalne Katalonije s visokom autonomijom unutar Kraljevstva. ${ }^{205}$ Junker je stava da je većina Španjolaca protiv odcjepljenja Katalonije, a nije sigurno ni da u Kataloniji postoji jasna većina za odcjepljenje. ${ }^{206} \mathrm{Na}$ prvom referendumu za neovisnost izlaznost Katalonaca nije bila uvjerljiva, drugi je opstruiran, stoga se ne zna pravi broj Katalonaca koji nisu za odcjepljenje. Po broju zastupnika u katalonskom Parlamentu zaključilo bi se da je oko četrdeset posto Katalonaca za secesiju, a ostali su ili za nastavak života u Uniji ili za neki „treći put“. Zbog toga je katalonsko društvo duboko podijeljeno. Od uspostave višestranačja u Španjolskoj politički život Katalonije vrlo je složen jer nije određen samo podjelom na „lijeve ili

203 Brilmayer, L., Secession and Self Determination: A Territorial Interpretation, Yale Journal of International Law 1991, Vol. 16, str. 177. in: D’Amato, A., (ed.) International Law Anthology, Anderson Publishing Co, 1994, str. 197.

204 Postavljeno je pitanje $s$ kojim se od sljedećih izjava najviše identificiraju. Istraživanje je rađeno na uzorku 1.200 ispitanika u Barceloni (885), Gironi (119), Lleidi (70) i Tarragoni (126). National Identity of People in Catalonia, November 2017, The Statistics Portal - Statista, https://www.statista.com/statistics/326790/catalans-on-the-political-spectrum/.

205 Borgen, From Kosovo to Catalonia, op. cit. (bilješka 37), str. 1016.

206 Jean-Claude Juncker, "Nationalism is Poison", November 20, 2017, na https://elpais.com/elpais/2017/11/20/inenglish/1511177283_048948.html/. 
desne“, nego i time jeste li „za neovisnost ili ostanak unutar Španjolske“, jeste li za „katalonsko ili španjolsko“. ${ }^{207}$ Ili priželjkuju neko treće rješenje.

Pravo na samoodređenje nesumnjivo je jedno od temeljnih normi međunarodnog prava. Kao što je Hannum primijetio, „moguće da niti jedna suvremena norma međunarodnog prava nije toliko snažno promovirana ili široko prihvaćena kao pravo naroda na samoodređenje “. ${ }^{208}$ Temeljna karakteristika prava na samoodređenje jest da je to kontinuirano pravo naroda. ${ }^{209}$ Samoodređenje mora biti kontinuiran proces i ne iscrpljuje se određenim trenutkom u povijesti. Iznimno je važno razumjeti samoodređenje kao kontinuiran proces koji omogućava narodima da ostvare i održe trajnu kontrolu nad različitim pravnim, političkim i drugim područjima života, očuvaju svoj etnički ili nacionalni identitet, ostvare svoje individualne i grupne ljudske potrebe i interese, osnaže socijalnu pravdu te upravljaju svojim prirodnim bogatstvima bez vanjskog/stranog miješanja. Suzbijanje nacionalnih osjećaja i inzistiranje da jedan definiran i ekonomski jak narod s visoko razvijenom političkom autonomijom mora po svaku cijenu ostati u državi s čijom se politikom ne slaže, protivi se temeljima demokracije u liberalno-demokratskim državama. Isključivanjem mogućnosti promjene Ustava Španjolske 1978. godine., čak i odbijanjem razgovora o tome te zbog dugogodišnje nemogućnosti rješavanja te ozbiljne ustavne krize od strane središnjih španjolskih vlasti, stvorena je situacija nekakve demokratske represije Madrida prema Barceloni. U srži samoodređenja trebao bi biti slobodan izbor naroda, onog u nedemokratskom, kao i onog u demokratskom okruženju, pravo naroda da izabere reprezentativnu vlast i državno uređenje koje smatra najprikladnijim i to sve na demokratskim izborima. Zahtjevi i argumenti Katalonaca uvjerljivi su i stoga trebaju imati (barem) pravo na referendum o svojoj budućnosti. No španjolske vlasti i dalje nisu spremne donijeti zrelu političku odluku da im taj demokratski izbor omoguće, a snažan vjetar u leđa daju im i međunarodne i regionalne organizacije.

\section{ZAKLJUČNA RAZMATRANJA}

Secesionistički pokreti trajan su problem međunarodne zajednice i fenomen u pravnom i političkom smislu. Postojeće norme međunarodnog prava o samoodređenju nedostatne su i nepotpune. Važno je što preciznije utvrditi ispunjava li konkretna skupina kriterije da bi se smatrala narodom, pod kojim uvjetima to pravo može ostvariti te na koje aspekte samoodređenja ima pravo. Trebalo bi pažljivije poraditi na donošenju novih odredbi i/ili davanjem novih tumačenja postojećim međunarodnopravnim odredbama u okviru međunarodnih i regionalnih organizacija. ${ }^{210}$ Institucionalizacija i normativizacija samoodređenja, a u okviru toga, posebno osjetljivo pitanje odcjepljenja, nije lako provediva u UN-u. No, mogla bi biti nešto lakše provediva unutar EU-a. Secesiju je nemoguće ignorirati, stoga je očekivano da će EU biti puno važniji pri stvaranja ključnih normi (ili bar smjernica) povezanih s nastankom novih država

207 Kleiner-Liebau, op. cit. (bilješka 4), str. 73.

208 Hannum, Autonomy, Sovereignty, and Self-Determination, op. cit. (bilješka 7), str. 27.

209 Cassese, op. cit. (bilješka 2), str. 54.

210 Ibidem. 
u Europi, nego što bi to očekivali od Međunarodnog suda i/ili UN-a općenito. ${ }^{211} \mathrm{~S}$ tim u vezi, možemo se složiti s Mancini da „demoniziranje secesije i pretvaranje u ustavni tabu često potpiruje secesionističke zahtjeve“. S druge strane, ako je secesija prikazana kao jedno od mnogih prava i mogućnosti koje se nude subnacionalnim grupama u državama, šanse su da će „secesija izgubiti dosta od svoje privlačnosti“ ${ }^{212}$

Koji su ključni argumenti katalonskih secesionista? U prvom redu, višestoljetno očuvan kulturni (posebno jezični) identitet različit od ostatka Španjolske te kompaktno naseljavanje jasno definiranog teritorija na kojem brojčano dominiraju. Mogu se jasno definirati kao narod. Traumatičnost i teška represija Katalonaca u više od tri desetljeća Francove vlasti još uvijek su svježi u sjećanjima većeg broja Katalonaca, a te se povijesne nepravde i patnje često uzimaju kao važan razlog za separaciju od naroda kojeg smatraju odgovornim za te patnje. U tom se kontekstu pozivaju i na činjenicu da u Europi uspješno egzistira čitav niz manjih država. Jedan od ključnih argumenata prosecesionističkih snaga jest i činjenica da je Katalonija vrlo bogata regija, ekonomski dovoljno jaka da bude neovisna i samostalna. I narodi u demokratskim društvima imaju pravo na samoodređenje i slobodan izbor svoje pravno-političke budućnosti te se, smatraju secesionisti, samoodređenje mora shvatiti kao kontinuirani proces za svaki narod. Samoodređenje je usko vezano uz demokraciju i ne smije ga se ignorirati u demokratskim državama, čak štoviše.

Ključan kontraargument središnjih španjolskih vlasti jest pozivanje na Ustav Španjolske i vladavinu prava. Španjolska vlada uporno tvrdi da je za Kataloniju pravno nemoguće odcijepiti se od Španjolske, pozivajući se na čl. 2., čl. 8. i čl. 92. Ustava Španjolske. Podsjećaju da jednostrana secesija Katalonije od Španjolske ne samo da nije u skladu s Ustavom nego nije poduprta ni međunarodnim ni pravom EU-a. Time su čak i pregovori središnjih vlasti s Kataloncima oko secesije - neustavni. Katalonija nije, smatraju protivnici odcjepljenja, ovisno područje ni područje na kojem se događaju teška kršenja ljudskih prava. Unutarnje pravo na samoodređenje ostvareno je i iscrpljeno jer žive u demokratskoj i visoko decentraliziranoj državi. Stoga, smatraju središnje španjolske vlasti, nema mjesta za primjenu ,remedijalne secesije“. Antisecesionisti uporno prijete Kataloniji da, ako se odcijepe, izlaze iz EU-a, ali i iz stotina drugih međunarodnih i regionalnih organizacija kojih je Španjolska članica. Čeka ih neizvjesna budućnost članstva i apliciranje za stotinu međunarodnih i regionalnih organizacija. Proces učlanjivanja može potrajati godinama, a šteta nastala izlaskom iz tih velikih sustava može biti nepopravljiva ili barem dugotrajna, smatraju kontrasecesionisti. Također, predbacuju secesionistima da pretjeruju u opisima fiskalnih odnosa Barcelone i Madrida i da su brojke o tome koliko prihoda odlazi iz Katalonije, a premalo se vraća - pretjerane.

Nema sumnje da bi i Španjolsku i Kataloniju odcjepljenje skupo stajalo. No negativne ekonomske posljedice secesije (pa i raspada država) preživjeli su i ekonomski puno slabije države od Katalonije. Konačno, ispunjavanje uvjeta za članstva u međunarodnim i regionalnim organizacijama sigurno bi bilo lakše jednoj Kataloniji, nego mladim državama u tranziciji prema demokraciji i onima ekonomski slabije razvijenim. Ako se stvori kritična masa glasača

211 Borgen, From Kosovo to Catalonia, op. cit. (bilješka 37), str. 1021.

212 Mancini, S., Secession and Self-Determination, u: Rosenfeld, M., Sajó, A., (eds.) The Oxford Handbook of Comparative Constitutional Law, 2012, str. 482., cit. prema Connolly, op. cit. (bilješka 12), str. 103. 
za neovisnost, Španjolskoj će biti iznimno teško zadržati Kataloniju unutar svojih granica. ${ }^{213}$ Vješte političke elite u Kataloniji zasigurno će izazvati barem federalizaciju države, ako ne i neovisnost, jer središnje španjolske vlasti očito nemaju uvjerljivo rješenje ove duboke ustavne krize. ${ }^{214}$ Izbjegavanje pregovora sa secesionistima, odbijanje federaliziranja države, jačanje nezadovoljstva katalonskog naroda, produbljivanje podjela unutar katalonskog i španjolskog društva itd., moglo bi dodatno ojačati secesionističke zahtjeve i legitimizirati ih. Upravo su pregovori britanskih i škotskih vlasti oko neovisnost, politička zrelost britanskih vlasti, dobra pravna i ekonomska pripremljenost kontrasecesionista i samopouzdanje u vlastiti pravni i politički sustav, odnijeli pobjedu UK-a protiv škotskih secesionista. Vjerujemo da bi to bio dobar put i za španjolske vlasti. Na temelju tih dvaju primjera naroda koji se bore za odcjepljenje od bogatih i uspješnih europskih država na čijem teritoriju prebivaju, vidimo koliko je kompleksan odnos demokracije i prava na samoodređenje, odnosno svu složenost, kontroverznost i težinu suvremenog prava na samoodređenje. U praksi se višekratno pokazalo da je samoodređenje (iznimno) teško ostvariti u nedemokratskim okruženjima, ali jasno je da samoodređenje nije ništa manje stresno i zahtjevno ostvariti i u funkcionalnim demokracijama, pogotovo kada uključuje secesionističke zahtjeve.

\section{LITERATURA}

1. Armstrong, Kenneth, An Independent Scotland in the Europe-an Union, Cambridge Journal of International and Comparative Law, Vol. 3, No. 1, 2014., str. 181.-195.

2. Armstrong, Kenneth, The Reach and Resources of European Law in the Scottish Independence Referendum, u: Closa, Carlos, (ed.) Secession from a member state and Withdrawal from the European Union - Troubled Membership, Cambridge Universtiy Press, 2017.

3. Blanke, Hermann-Josef, Abdelrehim,Yasser, Catalonia and the Right of Self-Determination from the Perspective of International Law, Max Planck Yearbook of United Nations Law Online, Brill, Vol. 18, No. 1, 2014., str. 532.-564.

4. Bookman, Milica, The Economics of Secession, St Martin's Press, New York, 1992.

5. Borgen, Christopher J., From Kosovo to Catalonia: Separatism and Integration in Europe, Goettingen Journal of International Law, Vol. 2, No. 3, 2010., str. 997.-1033.

6. Borgen, Christopher J., The Language of Law and the Practice of Politics: Great Powers and the Rhetoric of Self-Determination in the Cases of Kosovo and South Ossetia, Chicago Journal of International Law, Vol. 10, No.1, 2009., str. 1.-34.

7. Bourne, Angela K., Europeanization and Secession: The Cases of Catalonia and Scotland, Journal on Ethnopolitics and Minority Issues in Europe, Vol 13, No 3, 2014., str. 94.-120.

8. Brilmayer, Lea, Secession and Self Determination: A Territorial Interpretation, (Vol. 16 Yale Journal of International Law, 1991) u: D’Amato, A., (ed.) International Law Anthology, Anderson Publishing Co, 1994., str. 325.-331.

9. Buchanan, Allen, Justice, Legitimacy, and Self-Determination: Moral Foundations For International Law, Oxford Political Theory, Oxford, 2007.

213 Blanke and Abdelrehim, op. cit. (bilješka 44), str. 544.

214 Ibidem. 
10. Buchanan, Allen, Democracy and Secession, u: Moore. Margaret, (ed.) National Self-Determination and Secession, Oxford University Press, Oxford New York, 1998.

11. Carla, Andrea, Institutions, Ethno-nationalism, and Sense of Belonging: Comparing Separatist Tendencies in Catalonia and South Tyrol, 11 European Yearbook of Minority Issues, Issue 1, 2012., str. 91.-121.

12. Cassese, Antonio, Self-Determination of Peoples: A Legal Reappraisal, Cambridge University Press, 1998.

13. Climent-Ferrando, Vicent, Immigration in Catalonia, in Search of a Public Philosophy, Interdisciplinary Research Group on Immigration (GRITIM - UPF), Universitat Pompeu Fabra, Barcelona, 2012.

14. Closa, Carlos, (ed.) Secession from a Member State and Withdrawal from the European Union, Troubled membership, Cambridge University Press, 2017.

15. Coggins, Bridget L., The History of Secession: An Overview, u: Pavkovic, Aleksandar, Radan, Peter, (eds.) The Ashgate Research Companion to Secession, Routledge 2011.

16. Connolly, Christopher K., Independence in Europe: Secession, Sovereignty, and the European Union, Duke Journal of Comparative \& International Law, Vol. 24, No 51, 2013., str. 51.-105.

17. Crawford, James, Boyle, Alan, Opinion: Referendum on the Independence of Scotland-International: Devolution and the Implications of Scottish Independence, Annex A, Presented to Parliament by the Secretary of State for Scotland by Command of Her Majesty, HM Government, 2013.

18. Crawford, James, The Creation of States in International Law, 2nd edition, Oxford, 2007.

19. Ćurko, Hrvoje, Politike nacionalnog identiteta slučajevi Španjolske i francuske Baskije, Fakultet političkih znanosti Sveučilišta u Zagrebu, Zagreb, doktorska disertacija, 2016.

20. Ćurko, Hrvoje, Profil autonomne zajednice Katalonija Zemlja na političkom raskrižju, Političke analize, god. 4, br. 15, 2013., str. 43.-48.

21. Dewdney, Richard, Results of devolution Referendums (1979 \& 1997), Research Paper no. 97/113, Social and General Statistics Section, House of Commons Library, November 10, 1997.

22. Edward, David, EU Law and the Separation of Member States, Fordham International Law Journal, Vol. 36, 2013., str. 1151.-1168.

23. Ehrlich, Charles E., Ethno-Cultural Minorities and Federal Constitutionalism: Is Spain Instructive, Southern Illinois University Law Journal, Vol. 24, No. 2, 2000., str. 291.-318.

24. Galindez, Jesus De, Spain, Columbia Law Review, Vol. 54. No. 5, 1954., str. 809.-820.

25. Gonzales, Carmen, The Catalan National Identity and Catalonia's Bid for Independence, Connecticut Journal of International Law, Vol. 32, No. 2, 2016., str. 115.-146.

26. Gotovac, Miljenko, Kostadinov, Biljana, Autonomne zajednice u Španjolskoj, Pravnik: časopis za pravna i društvena pitanja, Vol. 42, No. 86, 2008., str. 23.-33.

27. Guibernau, M., Nations Without States: Political Communities in the Global Age, Michigan Journal of International Law, Vol. 25, Issue 4, 2004., str. 1251.-1282.

28. Hannum, Hurst, Autonomy, Sovereignty, and Self-Determination, University of Pennsylvania Press, Philadelphia, 1996.

29. Harff, Barbara, Gurr, T. Robert, Ethnic Conflict in World Politics, Westview Press, Oxford, 2004.

30. Hopkins, John, The Future of Sub-National Governments in a Supra-National World-Lessons from the European Union, Victoria University of Wellington Law Review, Vol 38, 2007., str. 19.-33.

31. Jerve, Eivind, Explaining Scottish and Catalan Secessionist Mobilization in the Framework of the EU, Master thesis, Department of Comparative Politics University of Bergen 2015.

32. Kleiner-Liebau, Désirée, Migration and the Construction of National Identity in Spain, Iberoamericana Editorial Vervuert S.L.U., Madrid, 2009. 
33. Kymlicka, Will, Multicultural citizenship - a liberal theory of minority rights, Clarendon Press, Oxford, 1996.

34. Kymlicka, Will, Federalism and Secession: At Home and Abroad, 13 Canadian Journal of Law \& Jurisprudence, Vol. 13, Issue 2, 2000., str. 207.-224.

35. Levites, Benjamin, The Scottish Independence Referendum and the Principles of Democratic Secession, Brooklyn Journal of International Law, Vol. 41, No. 1, 2015., str. 373.-405.

36. Levrat, Nicolas, The Right to National Self-determination within the EU: a Legal Investigation, ECPR General Conference Universitetet i Oslo, Oslo, September 6-9, 2017., https://ecpr.eu/Events/PaperDetails.aspx?PaperID=37223\&EventID=96/

37. Lloyd, Trevor, Union and Division in Europe, 52 International Journal, Vol. 52, No. 4, 1997., str. 546.-555.

38. Lulić, Mira, Muhvić, Davor, Status Baskije u Španjolskoj: odcjepljenje versus decentralizacija, Pravni vjesnik, god. 21, br. 3-4, 2005., str. 287.-309.

39. Lulić, Mira, Pravo na samoodređenje u suvremenom međunarodnom pravu, doktorska disertacija, Pravni fakultet, Zagreb, 2005.

40. Miley, Thomas J., The Constitutional Politics of Language Policy in Catalonia, Spain, Adalah's Newsletter, Vol. 29, October 2006.

41. Musgrave, Thomas D., Self-Determination and National Minorities, Oxford Clarendon, 1997.

42. Nihtinen, Atina L. K., Scotland's Linguistic Past and Present: Paradoxes and Consequences, Studia Celtica Fennica, Vol. 2, 2005.

43. Patrick, Thomas Y., The Zeitgeist of Secession amidst the March towards Unification: Scotland, Catalonia, and the Future of the European Union, Boston College International and Comparative Law Review, Vol. 39, No. 1, 2016., str. 195.-226.

44. Pavkovic, Aleksandar, Radan, Peter, (eds.) The Ashgate Research Companion to Secession, Routledge, 2011.

45. Perry, Frederick V., Rehman, Scheherazade, Secession, the Rule of Law and the European Union, 31 Connecticut Journal of International Law, Vol. 31, No. 1, 2015., str. 61.-91.

46. Piris, Jean-Claude, Political and Legal Aspects of recent Regional Secessionist Trends in some EU Member States (I), u: Closa, C., (ed.) Secession from a Member State and Withdrawal from the European Union, Troubled Membership, Cambridge University Press, 2017.

47. Pronto, Arnold N., Irredentist Secession in International Law, Fletcher Forum of World Affairs, Vol. 40, No. 2, 2016., str. 103.-122.

48. Richter, Dagmar et al., eds, Language Rights Revisited - The Challenge of Global Migration and Communication, Wolf Legal Publishers, Berliner Wissenschafts-Verlag 2012.

49. Scotoni, Pau Puig I, Exercising Self-Determination without Jeopardising the Rights of the Others: The Catalan Model, St. Thomas Law Review, Vol 14, No. 2, 2001., str. 395.-409.

50. Shaw, Jo, Unions and Citizens: Membership Status and Political Rights in Scotland, the UK and the EU, $\mathrm{u}$ : Closa, C., (ed.) Secession from a member state and Withdrawal from the European Union - Troubled Membership, Cambridge Universtiy Press, 2017.

51. Shaw, Malcolm N., Secession from an existing state to form a new state or states, International law, Cambridge University Press, 6th ed., 2008.

52. Thornberry, Patrick, The principle of self-determination, u: Warbrick, C., Lowe, V., (eds.) The United Nations and the Principles of International Law, Essays in memory of Michael Akehurst, Routledge, London, 1996. 
53. Tierney, Stephen, 'Should the People Decide?' Referendums in a Post-Sovereign Age, the Scottish and Catalonian Cases, Netherlands Journal of Legal Philosophy, Vol. 45, No 2, 2016., str. 99.-118.

54. Tierney, Stephen, Giving with One Hand: Scottish Devolution within a Unitary State, International Journal of Constitutional Law, Vol. 5, No. 4, 2007., str. 730.-753.

55. Tierney, Stephen, Legal Issues Surrounding the Referendum on Independence for Scotland, European Constitutional Law Review, Vol. 9, No.3, 2013., str. 359.-390.

56. Vidmar, Jure, The Scottish Independence Referendum in an International Context, The Canadian Yearbook of International Law, Vol. 51, 2013., str. 259.-288.

57. Vieytez, Eduard R., A New Political Status for the Basque Country, Journal on Ethnopolitics and Minority Issues in Europe, Vol. 12, No. 2, 2013., str. 79.-105.

58. Weiler, Joseph H. H., Slouching towards the Cool War; Catalonian Independence and the European Union; Roll of Honour; In this issue A Personal Statement, European Journal of International Law, Vol. 23, No 4, 2012., str. 909.-913.

59. Vukas, Budislav, States, Peoples and Minorities, RCADI, 1991, VI, Tome 231 de la collection, Martinus Nijhoff Publishers, The Hague/Boston/London, 1999.

60. Xabier, Arzoz, Linguistic Minorities in Spain, in: Richter, D. et al., (eds.) Language Rights Revisited - The Challenge of Global Migration and Communication, Wolf Legal Publishers, Berliner Wissenschafts-Verlag, 2012.

61. Yakoviyk, Ivan V., Okladna, Marina G., Orlovskyy, Roman R., Separatism in the United Europe: Old Problems with a New Face, Проблеми законності, Issue 140, 2018., str. 132.-143. 
Mira Lulic**

\section{THE PHENOMENON OF SECESSIONIST DEMANDS IN DEMOCRATIC STATES: THE CASE OF CATALONIA COMPARED TO SCOTLAND}

\section{Summary}

The paper analyses the issue of Catalonia's request to secede from Spain. The first part of the paper deals with the historical development of Catalan demands for autonomy and independence. Thereafter, a more elaborate overview of modern times follows in the comparison of these secessionist demands to those by the Scottish secessionists. The paper provides a systematic review and analysis of Spanish legal regulations, in the first place referring to constitutional law, and other provisions of the national legal order relevant in this context. In addition to analysing whether the Catalan secessionists have the right to self-determination (and secession) under Spanish law, the issues are also analysed whether they are entitled to that right by international and/or EU law.

The demands for self-determination and secession outside the colonial context addressed to the central authorities in the modern and democratic multi-ethnic states have become the most demanding and controversial issues in international law and have triggered a great debate among scientists and experts. The phenomenon of secessionist movements in the liberal and economically powerful states thus gives a new dimension to self-determination as a continuous right, invoking the democratic right of the people to choose and vote on the legal, political, economic, and any other future of the area they inhabit. Such examples are exceptional and rare, hence important, because they provide an insight into whether and how secessionists can legalise and legitimise their demands for secession in liberal democracies.

Keywords: $\quad$ secession, self-determination, Catalonia, Scotland, EU, international law, constitutional law

\section{(c) (1) 8}

This work is licensed under a Creative Commons

Attribution-NonCommercial 4.0 International License.

Mira Lulić, PhD, Full professor, Chair of International Public and Private Law, Faculty of Law, Josip Juraj Strossmayer University of Osijek, Stjepana Radica 13, 31000 Osijek, Republic of Croatia. Email address: miral@pravos.hr. ORCID: https://orcid. org/0000-0003-3478-5099 